\title{
Technological Assessment of Different Solar-Biomass Systems for Hybrid Power Generation in Europe
}

\author{
C. M. Iftekhar Hussain \\ Technological University Dublin, iftekhar.hussain@mydit.ie \\ Brian Norton \\ Technological University Dublin, brian.norton@tudublin.ie \\ Aidan Duffy \\ Technological University Dublin, aidan.duffy@tudublin.ie
}

Follow this and additional works at: https://arrow.tudublin.ie/engschcivart

Part of the Power and Energy Commons

\section{Recommended Citation}

Hussain C.M.I, Norton. B. \& Duffy. A. (2016) Technological assessment of different solar-biomass systems for hybrid power generation in Europe. Renewable and Sustainable Energy Reviews (2016), doi:10.1016/j.rser.2016.08.016

This Article is brought to you for free and open access by the School of Civil and Structural Engineering at ARROW@TU Dublin. It has been accepted for inclusion in Articles by an authorized administrator of ARROW@TU Dublin. For more information, please contact arrow.admin@tudublin.ie, aisling.coyne@tudublin.ie, gerard.connolly@tudublin.ie.

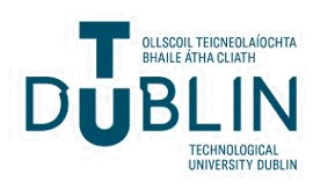




\title{
Technological assessment of different solar-biomass systems for combined heat and power generation in Europe
}

\author{
C. M. Iftekhar Hussain, Brian Norton, Aidan Duffy
}

Dublin Energy Lab, Dublin Institute of Technology, Grangegorman, Dublin 7, Ireland

\begin{abstract}
:
Solar Tower thermal (ST), Parabolic Trough thermal (PT), Linear Fresnel thermal (LF) and Solar PV are discussed in the context of suitability for hybridization with biomass in Europe. Technical, economical and climate data have been compared to identify the key drivers of technology selection in setting up large scale solar-biomass hybrid power plants. The sole solar-biomass hybrid power plant is currently in operation in Spain uses PT technology due to its performance characteristics, comparatively easy installation process compared to ST and relatively higher heat and optical gain than LF. The climate condition in the EU shows that the region within average yearly direct normal irradiance (DNI) $1400-1800 \mathrm{kWh} / \mathrm{m}^{2}$ can be useful for CSP hybridization as the distribution periods of high intensity of DNI of solar energy justify integrating biomass. Of the three concentrated solar power (CSP) technologies, ST provides the best overall efficiency for combined heat and power (CHP) generation.
\end{abstract}

\section{Introduction:}

Concentrating solar power (CSP) and solar PV are used increasingly for electric power generation due to their downward trend in installed costs [1-9]. However, standalone solar energy plants have intermittent energy output due to day/night cycles, reduced irradiation periods during winter, cloudy days and transient clouds [11, 15]. Although biomass power plants can operate continuously, they can have high initial cost, uncertain feedstock supply chain security, require the cost for infrastructure for bulk biomass storage and vehicles for transportation [10, 12]. Hybrid solar-biomass plants will become an increasingly attractive option as the cost of fossil fuel and land rise at the same time as the cost of solar thermal technology continues to fall [7]. There is one CSP-biomass hybrid power plant currently in operation in Spain, this study also intends to explore the potential viability of such power plants in other European climates [19].

There are a range of technical and economical assessments of solar power plant hybridized with conventional and nonconventional fuels, such as gas and coal, biomass and waste materials. Some have identified the risk factors and mitigation measures. This paper identifies the areas which are best match for combining solar and biomass technologies. 


\section{Current Deployment}

'Termosolar Borges' the only solar biomass hybrid power plant has been in operation which is located in Les Borges Blanques, Lleida, Spain since December 2012 with plant capacity of 22.5 MWe [1-4]. This hybrid electricity generation unit uses parabolic trough collectors with thermal oil to transfer heat of $400^{\circ} \mathrm{C}$ to the turbine [5]. According to a feasibility study prior to its commissioning, the location's direct irradiation was assumed to be $1.812 \mathrm{kWh} / \mathrm{m}^{2}$ year. The plant uses approximately 66.000 tons of biomass per year at $45 \%$ humidity which are mainly forest residue and agricultural crops collected from an extended area in Catalonia [6]. Electrical production sharing of this power plant is shown in Figure 1.

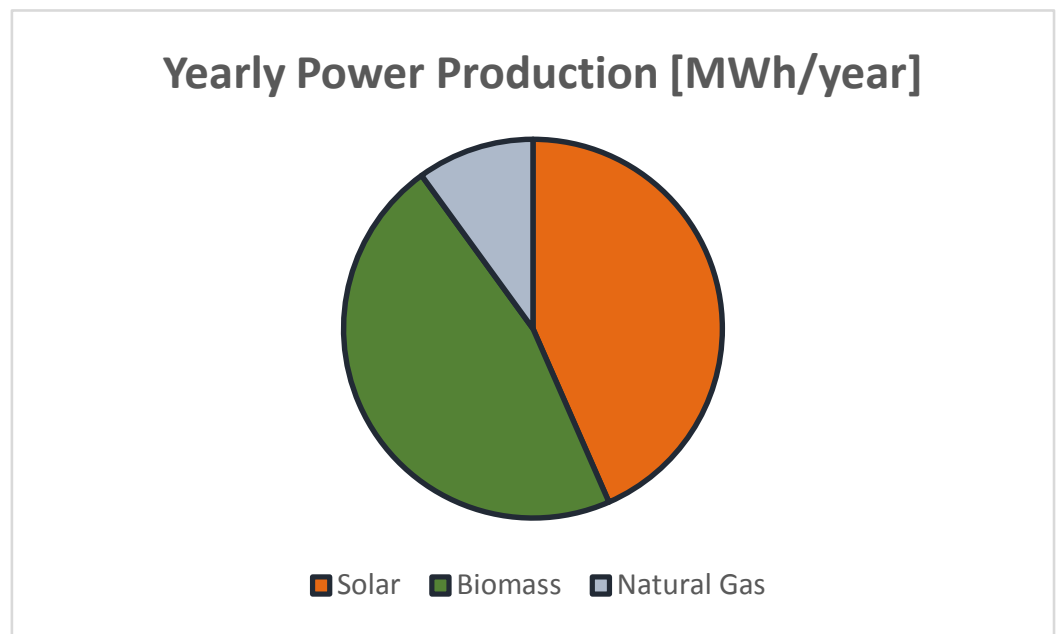

Figure 1. Termosolar Borges Generation Breakdown

Nixon et.al [7] assessed the feasibility of hybrid solar-biomass power plants in India for various applications including tri-generation, electricity generation and process heat. The study was performed on specific plant scenario of peak thermal capacities from 2 to $10 \mathrm{MW}$ by simulation models and case studies to evaluate technical, financial and environmental conditions. Although the levelized energy costs of a hybrid power plant was found to be higher than other conventional energy sources, it is competitive with photovoltaics and wind. The long payback periods for hybrid plants reflect the fact that they are not competitive with stand-alone biomass systems. However, a 1.2 - 3.2 times increase in feedstock price will result in hybrid systems becoming cost competitive. Furthermore, in comparison to biomass only, hybrid operation saves up to $29 \%$ biomass and land with an 8.3-24.8 \$/GJ/a \& 1.8-5.2 $\$ / \mathrm{kWh}$ increase in cost per exergy loss and levelized energy cost respectively $[7,13,19]$.

\section{Planed Deployment:}

Two "network integration request calls" were announced in Portugal in 2009. One for integrating of $28.5 \mathrm{MWe}$ from concentrated solar power plants ranging from 1.5MWe to $4 \mathrm{MWe}$ using different CSP technologies [10]. Another call was for of biomass power plants with an improvement in the feed-in tariff in 2010. These initiatives are part of the 2020 national 
strategic plan for renewable energies, where Portugal assumed to obtain $31 \%$ of the annual energy consumption from renewable sources by 2020. Coelho et.al study showed that in the Portuguese Algarve region the solar direct normal irradiation (DNI) can reach $2200 \mathrm{kWh}$ $\mathrm{m}^{2} /$ year, yearly biomass resources like forest and crop wastes are $1244 \mathrm{GWh}$, municipal solid wastes are $425 \mathrm{GWh}$, biogas from waste-water treatment plants are $219 \mathrm{GWh}$ and residues from agricultural and wood industry are 30 GWh $[10,14]$.

In Australia, there is no commercial standalone CSP plant due to policy uncertainty, insufficient risk mitigation procedure and comparatively high investment cost of CSP [1,6]. One hybrid plant has already started generating power from coal co-fired CSP plant in Liddell in New South Wales. Another coal co-fired CSP plant is under construction at Kogan Creek in Queensland. There are some other initial studies investigating with gas and biomass hybrids plant [8].

\section{Solar Resources:}

This section outlines solar irradiation of different areas in Europe to understand which technology suits best to a certain region in preference to the sun resource. From the data collected either by satellites or weather stations, a number of solar resource maps as shown in Figure 2 are available for Europe [19, 28 -43].

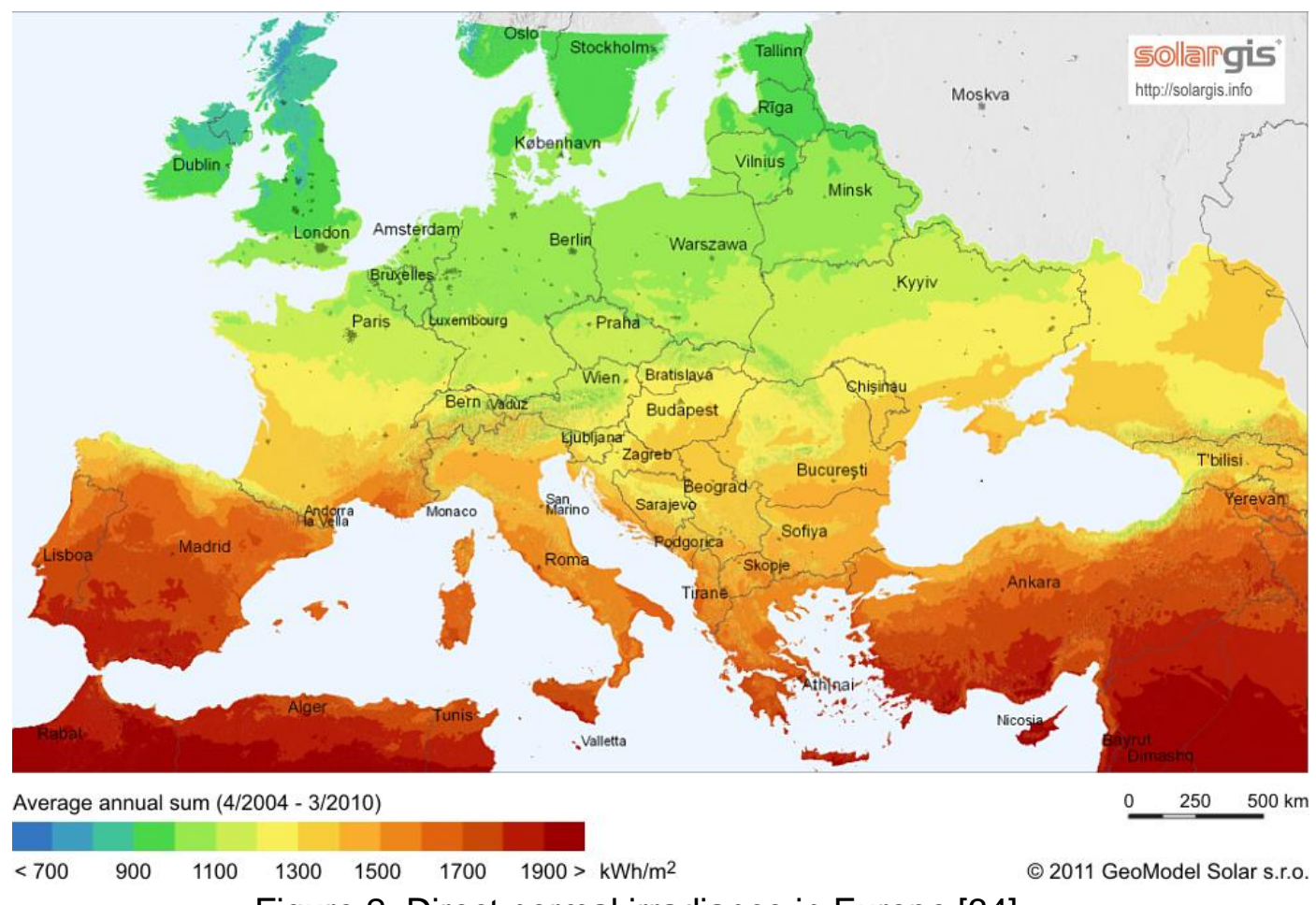

Figure 2: Direct normal irradiance in Europe [34] 
While reported solar resources differ slightly from one literature source to other, these differences are small and they provide some useful information on the suitability of different EU regions for large scale CSP and PV systems (Table 1).

Most of the European CSP power plants in operation are typically located within the average DNI range of $1800-2000 \mathrm{kWh} / \mathrm{m}^{2} /$ year. The DNI below that range may be useful for hybrid technologies. Indeed, the world's only hybrid solar biomass power plant is located in North East Spain, within the region of average annual solar insolation $1600-1800 \mathrm{kWh} / \mathrm{m}^{2}$. All other CSP power plant in Spain are located in southern Spain.

\begin{tabular}{|c|c|c|}
\hline $\begin{array}{l}\text { Global Horizontal } \\
\text { Irradiation } \\
\text { (kWh } / \mathrm{m}^{2} / \text { year) }\end{array}$ & Region & Suitability \\
\hline $1800-2000$ & $\begin{array}{l}\text { Southern Spain, Southern } \\
\text { Portugal, Southern Turkey }\end{array}$ & Very Favourable for CSP and PV \\
\hline $1600-1800$ & $\begin{array}{l}\text { Spain midlands, Northern } \\
\text { Portugal, Southern Italy, } \\
\text { Turkey, Southern Greece }\end{array}$ & Favourable for CSP and PV \\
\hline $1400-1600$ & $\begin{array}{l}\text { Southern France, Northern } \\
\text { Italy, Northern Greece }\end{array}$ & $\begin{array}{l}\text { Less favourable for CSP, good for } \\
\text { PV }\end{array}$ \\
\hline $1100-1400$ & $\begin{array}{l}\text { Northern France, Southern } \\
\text { Germany, Central Europe, } \\
\text { Romania, Bulgaria, Portugal, } \\
\text { Malta, Cyprus, most parts of } \\
\text { Spain, Italy, Southern France, } \\
\text { Greece and Southern Turkey }\end{array}$ & $\begin{array}{l}\text { Not favourable for CSP but good } \\
\text { for PV }\end{array}$ \\
\hline $1000-1200$ & $\begin{array}{l}\text { Southern UK, Germany, } \\
\text { Northern parts of Spain, Italy, } \\
\text { Croatia, Romania, Bulgaria } \\
\text { and Turkey }\end{array}$ & $\begin{array}{l}\text { Favourable for PV, } \\
\text { unfavourable for CSP }\end{array}$ \\
\hline $800-1000$ & $\begin{array}{l}\text { Ireland, Northern Europe, } \\
\text { France (except in the } \\
\text { North) ,Central Europe, } \\
\text { Southern Germany }\end{array}$ & $\begin{array}{c}\text { Relatively Less favourable for PV, } \\
\text { unfavourable for CSP }\end{array}$ \\
\hline 700 to 800 & $\begin{array}{l}\text { North France, Benelux, } \\
\text { Denmark, }\end{array}$ & $\begin{array}{l}\text { Less Favourable (The diffuse } \\
\text { radiation has a higher share. Due } \\
\text { to long daylight in summer, the }\end{array}$ \\
\hline
\end{tabular}




\begin{tabular}{|l|c|c|}
\hline & $\begin{array}{c}\text { Northern part of Central } \\
\text { Europe }\end{array}$ & $\begin{array}{c}\text { yearly sums of solar electricity } \\
\text { generation in the north west } \\
\text { Europe are almost the same as in } \\
\text { the lower latitudes of Western } \\
\text { Europe, unfavourable for CSP }\end{array}$ \\
\hline$>700$ & $\begin{array}{c}\text { Scotland } \\
\text { and the North Sweden and } \\
\text { Finland }\end{array}$ & Not favourable for PV and CSP \\
\hline
\end{tabular}

Table 1: Solar irradiation and suitability for CSP and PV power plants [19]

DNI range of 700 to $2000 \mathrm{kWh} / \mathrm{m}^{2}$ /year where vast PV plants are located in Europe. The effective zone for PV system is relatively bigger than CSP because of the characteristics of PV system to generate electricity from defused solar insolation. Although the region between 700-800 kWh $/ \mathrm{m}^{2} /$ year is not quite ideal for PV power generation but it can be targeted for small scale biomass hybrid system or solar thermal systems for water heaters. It may be useful for small scale power plants as both DNI and defused solar irradiation and long sun irradiate period in summer time could help PV systems to supplement power generation within the region where sun irradiation lies between $800-1000 \mathrm{kWh} / \mathrm{m}^{2} /$ year [45-50].

\section{Biomass Resources:}

This section presents information about the biomass resource across the Europe and some policy adopted in different European countries to encourage the advancement of power generation from biofuel. EU has seen a great demand of solid biomass to meets its renewable energy targets in last few years [19,51]. National Renewable Energy Action Plans (NREAPs) has provided an estimation of future biomass supply and demand up to 2020. In this Figure 3, total biomass supply of EU 27 is presented where the left columns represents NREAPs and the right columns shows Green-X model data. Figure 3 shows that the major suppliers of biomass are Germany, France, Spain and Poland. Most of those supplies are coming from both direct and indirect agriculture. However, there are also some gaps between two models. In forestry, NREAPs data differs from Green-X model in France, Poland and Germany. Energy crops in the NREAPs are significantly lower in France (12 Mtoe), Spain (9 Mtoe), Poland (9 Mtoe), Romania (7 Mtoe) and Italy (4 Mtoe). 


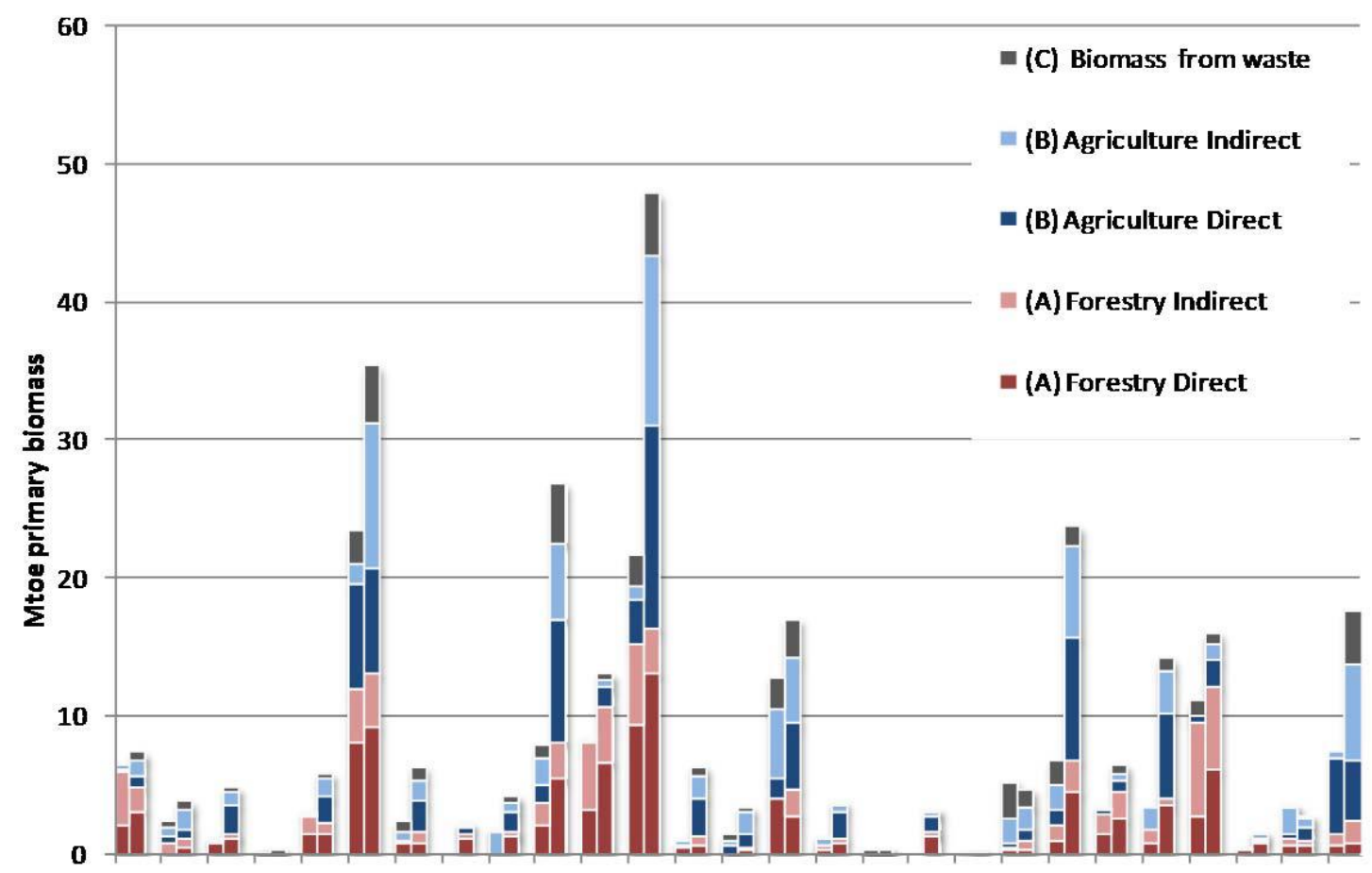

AT BE BG CY CZ DE DK EE EL ES FI FR HU IE IT LT LU LV MT NL PL PT RO SE SI SK UK

Figure 3. Biomass supply in the NREAPS and Green-X for the EU27 from primary, secondary and tertiary resources in 2020. The left columns are based on table 7a of the NREAPS (partly based on ECN 2011), the right columns show the potentials that are used in the Green-X model (Resch 2011). [51]

\section{Solar Receiver Technologies}

Different solar technologies including CSP and PV had been widely described in many publications. This paper presents a brief overview of some of the technologies for better understanding of technology selections on the following sections.

\subsection{Solar Tower}

Solar towers (central receiver technology) use heliostat dual-axis sun-tracking mirror to reflect the sun's heat onto a single receiver point [52-54]. The heliostats reflects direct normal irradiance of sun to a central receiver. This cumulative DNI generates a high temperature to produce superheated steam through heat transfer fluid. This superheated steam is eventually fed into a Rankine Cycle to operate a steam generator to produce electricity. Heat could be used for industrial processes, such as steam production for process heat (around $1000{ }^{\circ} \mathrm{C}$ ) and the charging of energy storage [55-57]. This heat and power production technology is inherently large scale. 


\subsection{Parabolic Trough}

Parabolic Trough collectors are made of long parabolic shaped mirrors consists of the receiver with the same length which is located on focal point of the mirror $[52,58]$. This is a one axis tracking technology which is typically aligned on east-west axis. The north-south axis harvests more energy in summer where east-west produces more in winter [59]. The tracking system rotates the collector on its single axis throughout the day to track the DNI of sun's energy, which reflects on to the receiver tube that contains either the synthetic thermal oil, molten salt or pressurized water. The temperature reaches to $400^{\circ} \mathrm{C}$ for thermal oil, $550^{\circ} \mathrm{C}$ for molten salt and $500^{\circ} \mathrm{C}$ for pressurized water. This produced heat is then transferred to either heat exchanger to feed it to Rankine cycle to produce electricity. The advantage of this technology is it's modularity as it can operate in both small and large scale and has moderate land use. Therefore, PT is an established technology in present market for electric power generation.

\subsection{Linear Fresnel}

Linear Fresnel collectors are one of two viable line-focus CSP technologies, along with the parabolic trough $[19,53]$. Linear Fresnel collectors utilize an array of low-profile, flat or nearly flat primary reflectors and a fixed receiver assembly that includes one or more linear receiver tubes and an optional secondary reflector. The primary reflectors track the sun in the daytime while the receiver assembly remains fixed. The low profile reflector architecture allows increasing concentration ratio without increasing wind loads, which is otherwise the case for parabolic troughs and large-sized heliostat mirrors for central-receiver systems. Historically, most linear Fresnel collectors were developed for low/medium-temperature heat generation. A linear Fresnel collector typically includes an array of mirror panels, so its design may differ in terms of the individual mirror dimensions and the overall arrangement. In addition, the fixed nature of the receiver assembly provides considerable design freedom. Linear Fresnel collectors have lower optical/thermal efficiency than parabolic troughs because the combination of a fixed receiver and the one-axis tracking mirror panels in a horizontal plane results into greater cosine losses than troughs [60-63]. The lower cost collector components are often required to compensate this optical penalty.

\subsection{Stirling Dish:}

In Stirling Dish technology, a parabolic dish shaped solar concentrator reflects the DNI to the receiver which is located on the focal point of the dish. This concentrator can generate temperature above $1000^{\circ} \mathrm{C}$ at the focal point where the electricity generators are located. The generators at the focal point could be either micro-turbine or Stirling engine. The dish is moved throughout the day to receive maximum DNI by using two axis sun tracking system. Two type of working fluids are used in this system. Helium as the working fluid drives free piston engine 
which has lower maintenance cost because it produces low friction. On the other hand hydrogen drives kinematic engine which has higher efficiency [52, 64].

\subsection{Solar PV}

Solar PV captures the sun's energy using solar photovoltaic (PV) cells. When sun light hits the panel DC current is produced. This DC current is then fed into an inverter to convert it to AC current for electrical appliances. Unlike the CSP technology PV system does not require direct sun irradiance to generate electricity. PV cells can generate DC current with defuse solar radiation. Much research had been conducted on large or small grid connected and offgrid PV power plant both for commercial and home use [65-71].

\subsection{Solar Pond:}

A salt gradient solar pond is usually a land covered by water with three different layer of salt density which receives insolation as a thermal energy [72-75]. The bottom of the pond consists salt with high concentration; the middle layer has lower concentration of salt and the top layer is fresh water. Pond depth is typically in range of 1 to $3 \mathrm{~m}$. Usually in the pond solar energy rises upward as warmer water has lower density. However, in solar pond this process is prevented by adding salt concentration. The salt consists of $\mathrm{NaCl}$ or $\mathrm{MgCl}_{2}$ or $\mathrm{NaHCO}_{3}$ in lower $40-50 \mathrm{~cm}$ of a pond prevents the convection heat transfer and establish density gradient. Thermal energy cannot travel toward top of the pond due to higher salt density of lower depth. The temperature rises up to $90^{\circ} \mathrm{C}$ through this by heat accumulation at the lower depth of pond and this heat can be used to store thermal energy to generate electricity. Unlike salt-gradient solar pond, gel solar pond contains a thick layer of floating polymer gel at lower convective depth. The gel has good property of optical and thermal insulation but the higher cost makes it economically less viable for commercialisation.

\subsection{Fixed Mirror Solar Concentrator:}

Fixed mirror solar concentrator (FMSC) is designed with static reflector and moving receiver and can typically produce thermal energy in medium range temperature [75]. The static reflector of FMSC is advantageous over other solar receiver technologies when it is integrated on the rooftop of a building. This technology can generate thermal heat in range of $80-250^{\circ} \mathrm{C}$ which can be used for industrial process heat. FMSC is not a proven technology for large scale electric power generation till to date due to its low efficiency. Li et.al[76] developed an Azimuth tracking system which improved optical performance by reducing shading effects of neighbouring reflectors for incident angle of less than $10^{\circ}$. The proposed system was validated by ray tracking results and showed that the design can produce temperature of $400^{\circ} \mathrm{C}$ with $61 \%$ efficiency. 


\section{High Temperature Energy Storage System:}

Two tank molten salt storage is the only commercially available concept for CSP plants with a large thermal capacity requirement. This storage system essentially consists of two tanks filled with molten salt at different temperature and fill levels. The molten salt consists $60 \% \mathrm{NaNO}_{3}$ and $40 \% \mathrm{KNO}_{3}$ which is otherwise also known as solar salt. This solar salt is utilized as the heat transfer fluid for the CSP power plant. The liquid molten-salt at $290^{\circ} \mathrm{C}\left(554^{\circ} \mathrm{F}\right)$ is pumped from cold storage tank and sent to the receiver where it is heated up to $565^{\circ} \mathrm{C}\left(1,049^{\circ} \mathrm{F}\right)$. This hot molten salt is carried from the receiver to a hot storage tank [15].Finally the hot salt is collected and sent to the steam generating system where superheated steam is produced. After generating the steam the hot molten salt loses heat and therefore the salt is returned from the steam generator to the cold tank where it is stored and eventually reheated in the receiver [77]. The Insulation of heat is very important for both hot and cold heat storage tank. This insulation prevents heat loss or energy loss and increase efficiency of the power plant. The heat transfer medium or fluids is a vital element of thermal energy storage system. Molten salts is used as heat transfer fluid and kept into an insulated storage tank. Molten salt has been chosen for this technology because of its liquidity property at atmosphere pressure, its efficiency and, low cost [78]. Furthermore, its operating temperatures are compatible with today's high pressure and high- temperature steam turbines, and it is non-flammable and nontoxic.

\section{Biomass Technologies}

Figure 4 shows two major conversion routes are considered for biomass such biochemical and thermochemical. In biochemical processes there are two more routes mostly known as digestion (anaerobic and aerobic) and fermentation [19,79].

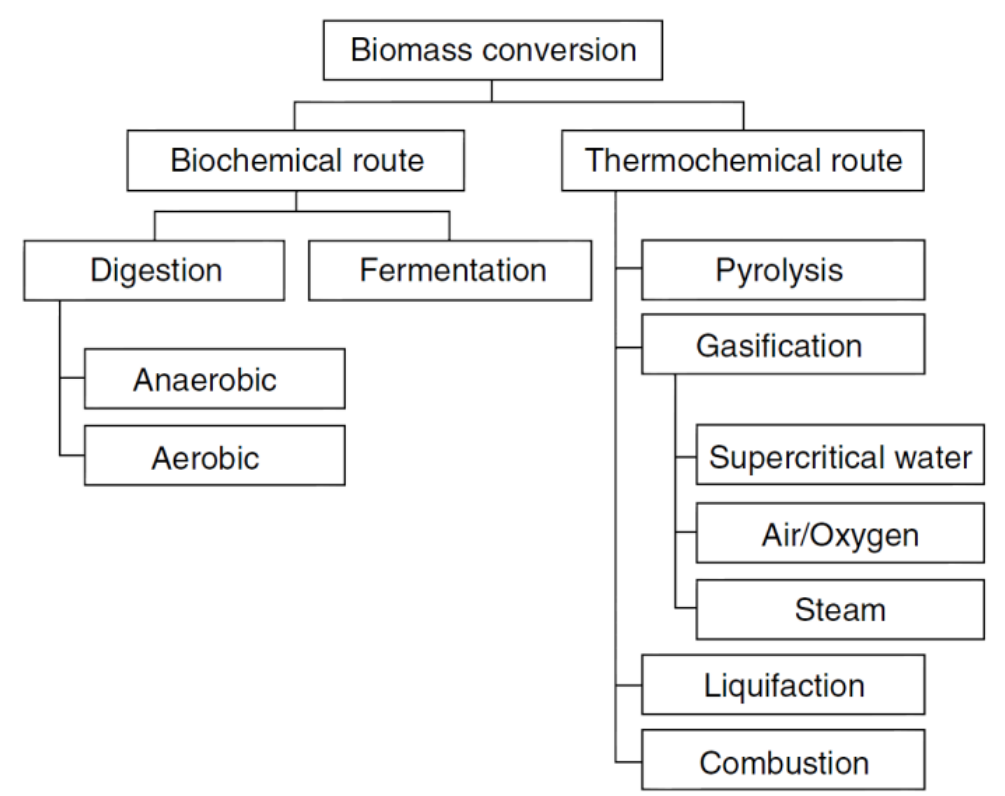

Figure 4: Conversion routes for biomass [79,82] 
In this review two of thermochemical conversion routes will be considered. Biomass combustion involves complete conversion of biomass in excess oxidant (usually air) to $\mathrm{CO}_{2}$ and $\mathrm{H}_{2} \mathrm{O}$ at high temperature. Gasification converts biomass in an $\mathrm{O}_{2}$ deficient environment. Pyrolysis takes place at a relatively low temperature in the total absence of $\mathrm{O}_{2}$ [80].

\subsection{Biomass Gasification:}

Gasification is a process where carbonaceous fuel is converted to a combustible gas known as syngas, consisting of $\mathrm{H}_{2}, \mathrm{CO}, \mathrm{CH}_{4}, \mathrm{CO}_{2}, \mathrm{H}_{2} \mathrm{O}, \mathrm{N}_{2}$, higher hydrocarbons and impurities (e.g. tars, $\mathrm{NH}_{3}, \mathrm{H}_{2} \mathrm{~S}$ and $\mathrm{HCl}$ ) [79]. The process starts if certain amount of pure $\mathrm{O}_{2}$ air and steam otherwise known as oxidant reacts with available carbon at high temperatures in a fuel within a gasifier. Gasification converts biomass to a gas which can generate power. Researchers found that gasification has higher electrical efficiencies compared to combustion based technologies because the converted gas can usually generates advanced power like fuel cell $[81,82]$. It also offers greater flexibility in applications of electricity, heat, transport fuels and chemicals. Figure 5 represents the process of biomass gasification.

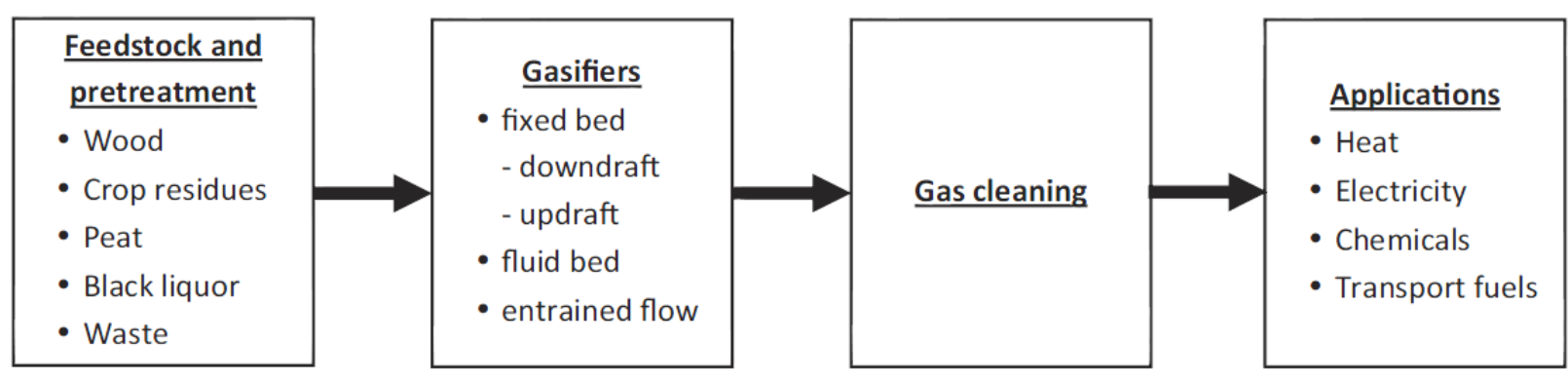

Figure 5: Gasification Process: [82]

Gasification plant is typically consists of following units:

$>$ Gasifier

$>$ Syngas cleaning units (engine/turbine requirements)

$>$ Gas engine/turbine with generator (power generation plant

$>$ Heat recovery/steam generation

> Steam engine/turbine with generator (combined cycle plant)

\subsection{Biomass Combustion}

Combustion is a chemical reaction in which a fuel is oxidised releasing a large quantity of energy. Hot gas produced by burning biomass in a combustor or furnace. This gas is then fed into a boiler in order to generate steam. The steam drives a turbine or steam engine to produce electricity [83-85]. Figure 6 presents combustion process.

Biomass combustion is suitable for commercial process heat/district heat, $\mathrm{CHP}$, and electricity generation ranging from a few MW up to 50-100 MW. This technologies adopts either Fixed 
Bed (underfeed stoker \& fixed or moving grate) or Fluidised Bed (bubbling \& circulating fluidised bed) or Entrained Flow or Dust Combustor to convert energy from biomass. Technology selection depends on the plant scale and type \& quantity of biomass fuel available. Following figure shows process of biomass combustion.

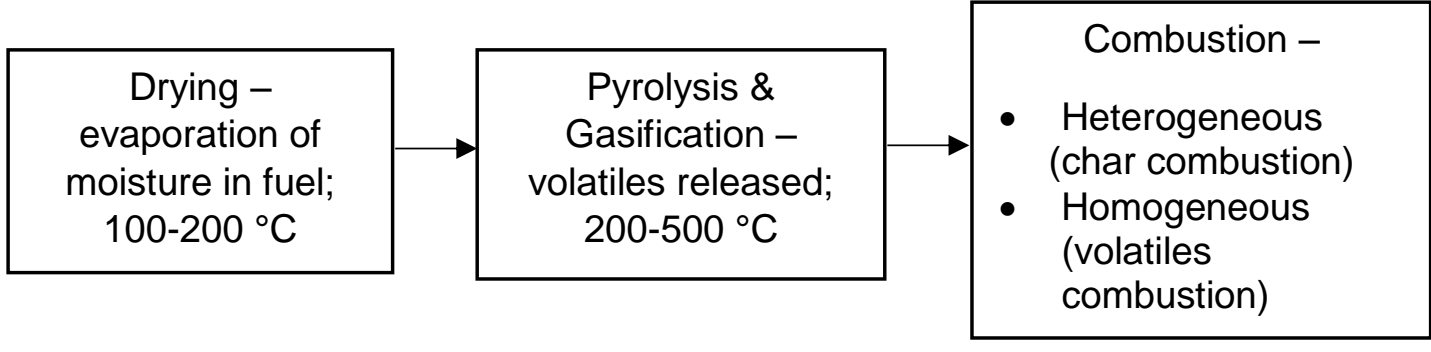

Figure 6: Combustion Process [84]

Combustion plant is typically consists of following units:

$>$ Furnace/boiler

$>$ Heat recovery/steam generation

$>$ Steam engine/turbine with generator (power generation plant)

\section{Overview of System Options:}

A good number of research had been conducted on working characteristics and performance of both solar PV and concentrating solar power (CSP) plant in different scenarios [19,52, 6471, 86-104]. Stirling dish which is one of the most prominent CSP technologies and offers a better system efficiency over all other CSP. The system consists of a Stirling engine at each focal point of the parabolic dish which generate electricity. The unique technical characteristics of Stirling Dish does not allow sharing of plant equipment like cooling systems and power blocks as with other CSP technologies when integrated with biomass. Only one such kind of power plant using Stirling dish technology has been operating since 2010 in Peoria, Arizona. Thus it is very unlikely to find a solar Stirling dish hybrid system with biomass for both power and heat generation.

Different research found that due to the high cost and land involvement, Solar pond technology may be suitable for small scale operation. Large solar pond can be deployed for multiple applications such as power generation, thermal energy storage, space or industrial process heating to make the plant economically viable $[73,76]$. Solar Pond has immense potentiality to be deployed for power generation and energy storage system. Singh et.at demonstrated a small scale power plant using low grad heat from solar pond which can be utilized for small scale applications [74]. The plant is capable of generating $9.56 \mathrm{~W}$ of power with $15.67 \mathrm{~V}$ and $0.61 \mathrm{~A}$ at the temperature of $100^{\circ} \mathrm{C}$. Although some modelled FMSC plant 
had been presented in some research producing higher temperature like PT and LF, but there are no reference large scale electric power generation plant currently in operation.

As this review study concentrates on large scale power system with high grad heat generation. Only CSP with biomass systems will be discussed in the following paragraphs. Peterseim et.al [4] examined 17 different combinations of CSP-biomass and storage systems in his study. In a different study Bhattacharjee S et.al [107] examined grid-tie solar PV and biomass hybrid system for power generation. Among various combinations of system this paper discusses three best performing combinations of CSP and one system of solar PV in respect to technical and economic aspect in Europe.

\subsection{Option 1: Solar Tower Combined With Biomass}

Among all other concentrating solar power technologies, Solar Tower (ST) or Central Receiver Systems (CRS) is able to produce highest temperature $>500^{\circ} \mathrm{C}$ and steam pressure (up to 130 bar) and provide better efficiencies in electricity and heat production $[105,106]$. Solar tower system can operate with Direct Steam Generation (DSG) or Molten Salt for storage system in terms of power generation. DSG is particularly preferable for its higher efficiency, on the other hand molten salt enables power plant to produce electricity during insufficient DNI. Solar tower with molten salt is also and commercially available from different suppliers.

Among 17 different combinations which had been studied previously [4], solar tower (ST) with direct steam generation (DSG) as primary CSP working fluid combining with biomass gasification gave the highest peak net efficiency of $33.2 \%$ followed by the combination of solar tower, molten salt (primary CSP working fluid) and gasification with optimum net efficiency $32.9 \%$. Both systems are able to produce $540^{\circ} \mathrm{C}$ temperature at 130 bar steam pressure. On the other hand at $525^{\circ} \mathrm{C}$ and 120 bar steam pressure ST/DSG/biomass combustion system can provide $33.0 \%$ of pick efficiency followed by ST/molten salt/ biomass combustion of $32.8 \%$ efficiency. From the above information it appears that biomass gasification gives marginally higher efficiency comparing with combustion system when it merge with CSP. Within the CSP, molten salt as the working fluid is slightly less efficient than DSG. In terms of heat storage, usually molten salt may be best in present time for solar tower technology.

On the same research it was found the economically the internal rate of return of DSG with combustion and gasification system is $10.8 \%$ and $10.9 \%$ respectively in comparison to molten salt with combustion and gasification both $10.5 \%$. The payback period of the first case is 9.7 and 9.6 and the second case gives 10.2. The reason behind the better economic performance of DSG than molten salt is the capital expenditure of setting up a large storage facilities for molten thermal energy storage (TES) system. 


\subsection{Option 2: Linear Fresnel Combined With Biomass}

Linear Fresnel is also an option for hybridization with biomass resource and this systems has also been investigated in various research [106, 108,109]. Although LF systems is capable of obtaining from $400^{\circ} \mathrm{C}$ to 500 temperature at steam pressure from 90 bar to 110 bar which is less than ST technology, however no such power plant had been found which combines linear Fresnel with molten salt for heat storage. At $500^{\circ} \mathrm{C}$ temperature and 110 bar steam pressure LF with DSG as primary working fluid can provide net plant efficacy of $32.5 \%$ when it combines with biomass combustion system [4].

Among all CSP biomass hybrid system, LF use to give the best economic performance. The same system can give an IRR of $11.5 \%$ with only 8.6 years of payback period. The research also indicates that Fresnel technology offers much lower investment cost in comparison to other two CSP technology.

\subsection{Option 3: Parabolic Trough Combined With Biomass}

Parabolic Trough (PT) technology hybridized with biomass is most mature system among all of the hybrid technologies as there is one such plant is currently operating in Spain. It had been found that PT with DSG in combination with biomass combustion system at temperature $450^{\circ} \mathrm{C}$ and 100 bar steam pressure can obtain pick net efficiency of $31.5 \%$ [4]. On the other hand PT with molten salt at $525^{\circ} \mathrm{C}$ and 120 bar can give the efficiency of $32.7 \%$. If the biomass technology adopts gasification, the same combination with PT and molten salt can provide slightly more efficient system of $32.8 \%$ and able to obtain temperature of $540^{\circ} \mathrm{C}$ at $130 \mathrm{bar}$ steam temperature. It indicates clearly that gasification has higher conversion efficiency it is although not very significant $[92,110]$.

The economic scenario is not however, as competitive as other two CSP technologies. PT, DSG and biomass combustion will see $8.9 \%$ of IRR on investment with 14.6 years of payback time. Other two combinations will give a little better IRR which is $9.0 \%$ and $9.1 \%$ respectively. The payback period is also marginally better which is 14.4 years and 14.3 years. No LCOE had been presented in this particular research. LCOE of PT-biomass hybrid system could be more useful in understanding the suitability of this system for electricity and heat generation.

\subsection{Option 4: PV Combined With Biomass}

Unlike CSP technology solar PV generates power from direct conversion of light into electricity at the atomic level. As mentioned previously photovoltaic produces DC current which than requires to convert in to $A C$ current to drive most of the electric equipment. PV power plants can be integrated to both in off-grid or grid-tie system and is also capable of store energy through batteries which provides DC current. In this case, heat is not one of the desirable byproduct which puts this system in low rank for both power and heat generation. However, in 
integration with biomass can give the system slightly more advantage to consider it as a good option for power generation from hybrid source. Few researches had been conducted on this technology in various place which targeted purely for electricity generation [111-116].

Some specific plant scenario had been modelled of which Bhattacharjee S et.al [112] presented a PV biomass grid-tie power plant for rice mill in India. This particular plant uses mainly rice husk and immature paddy for biomass resources. In model, the size of the PV array is $25 \mathrm{kWp}$ with $20 \mathrm{~kW}$ inverters and biomass generator operates with capacity of $6 \mathrm{~kW}$. It was presumed in the study that the costs of the system components are likely to decrease in future. When cost of both of the biomass unit and PV decreases by $50 \%$, the biomassgenerator capacity increases to $7 \mathrm{~kW}$ whereas the $\mathrm{PV}$ array capacity remains same as before, i.e., $25 \mathrm{~kW}$. In this consideration, the initial capital cost decreases by 53.3\%, NPC decreases by $84.7 \%$, and COE decreases by $56.64 \%$. Renewable fraction, capacity shortage, increase in biomass consumption in gasifier and generator operating hour are again found to be 0.96 , $0.02,21$ ton and $1985 \mathrm{~h}$. However, no analysis for energy storage system such as battery backup has been found in this research.

Although the PV-Biomass system were evaluated in some research, none of them presented convincing data for commercialization. This type of power plant is suitable for small scale generation system rather than utility scale. However, in Europe where sun DNI is not favourable for CSP and where biomass resources are sufficient this hybrid technology can be useful in terms of small scale power generation for both home and commercial facilities.

\section{Comparison of Options}

Sharing plant equipment of CSP-biomass hybrid system can lower the capital cost [1-6, 19]. On the other hand, no such reference had been found for PV-biomass hybrid system. As PV and biomass follows different operating procedure, it is very unlikely that this type of hybrid plant will share same components and thus lead to a reduction of capital cost. The following, therefore, presents technical comparisons between different standalone CSP and biomass technologies for better understanding of their technical characteristics and hybridization compatibility.

\subsection{CSP Standalone:}

Table 2 shows the comparison of peak solar to electricity conversion efficiency in relation to their land use. Although LF has better opportunities for large scale power plant development in terms of land use, but lacks with overall efficiency. A different research found that LF requires 35\% smaller solar field due to smaller row-to-row distance when it compares with PT $[19,117,120,121,124-126]$. ST can reach up to $27 \%$ efficiency at its peak at higher cost in terms of land use. Thus in CSP based power generation industry parabolic trough are most 
prominent among these three technologies due to its moderate land use and relatively better conversion efficiency.

\begin{tabular}{|l|c|c|}
\hline \multicolumn{1}{|c|}{ Technology } & $\begin{array}{c}\text { Peak Solar to Electricity Conversion } \\
\text { Efficiency }\end{array}$ & Land Use m²/MWh \\
\hline Solar Tower & $23-27 \%$ & $8-12$ \\
\hline Parabolic Trough & $21-25 \%$ & $6-8$ \\
\hline Linear Fresnel & $18-22 \%$ & $4-6$ \\
\hline
\end{tabular}

Table 2: Comparison of different CSP technology [121]

The experiment of Figure 7 was done by using data for Daggett, California where annual DNI is around $2791 \mathrm{~kW} \mathrm{~h} / \mathrm{m}^{2}$. Horizontally placed collectors of LF observes higher cosine losses causing higher optical losses. Cosine losses typically occurs if the surface is not normal to the sun, thus reduce the solar irradiance to the surface $[36,39]$. Figure 7 shows that during early morning and late afternoon optical efficiency is reduced due to the shading of a LF adjacent collector array. This also increases higher thermal energy dumping or lower dumping for these period of time. At mid-day, however, LF can capture maximum irradiance and produce higher thermal energy which exceeds the capacity of the power block causing higher upper dumping.

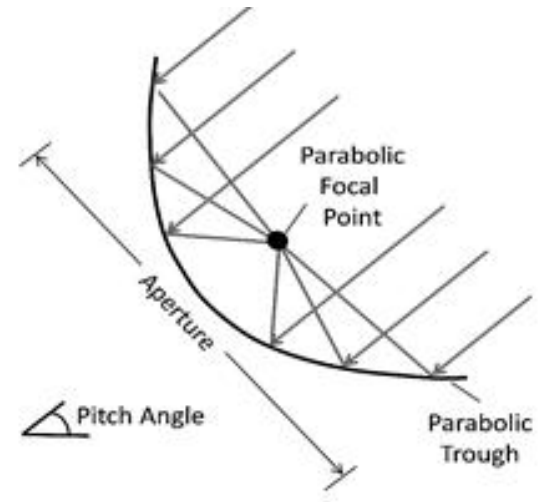

Parabolic Trough Collector, June 15

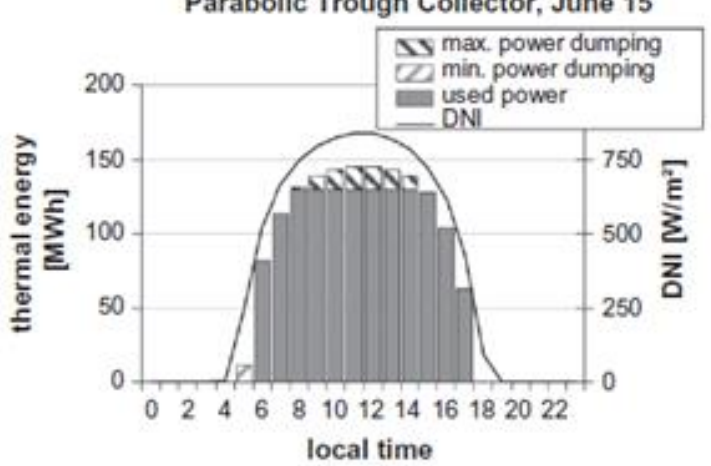

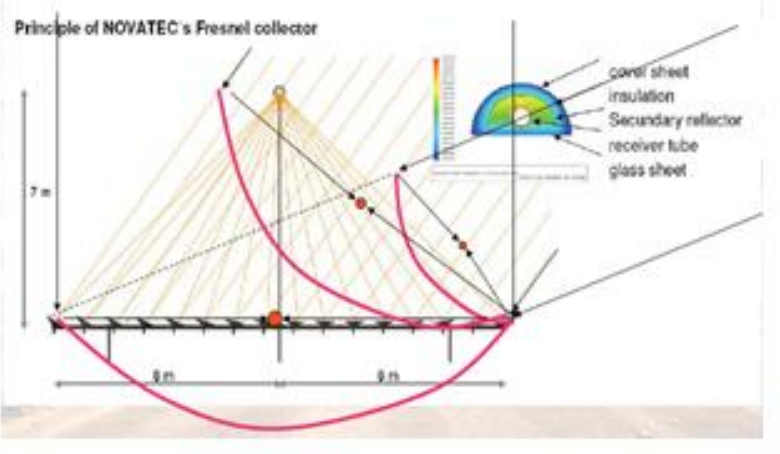

FRESDEMO Collector, June 15

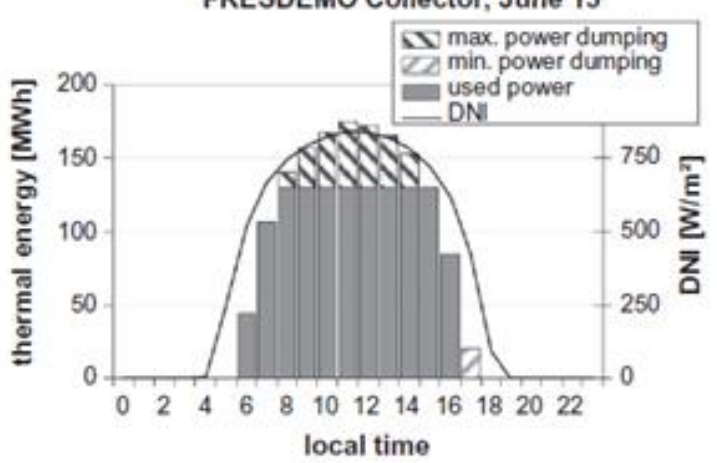

Figure 7: Dumping effect of parabolic trough and linear Fresnel $[124,125]$ 
In case of PT and ST, few more research have been carried out to evaluate the performance of each systems $[118,119,122,123]$. Simulation studies have shown that solar tower performs well in thermal energy generation which allows better cycle efficiency. This experiment was performed in Sevilla, southern Spain where annual yearly DNI is between1800 -1900 kWh/m² according to figure 2 .
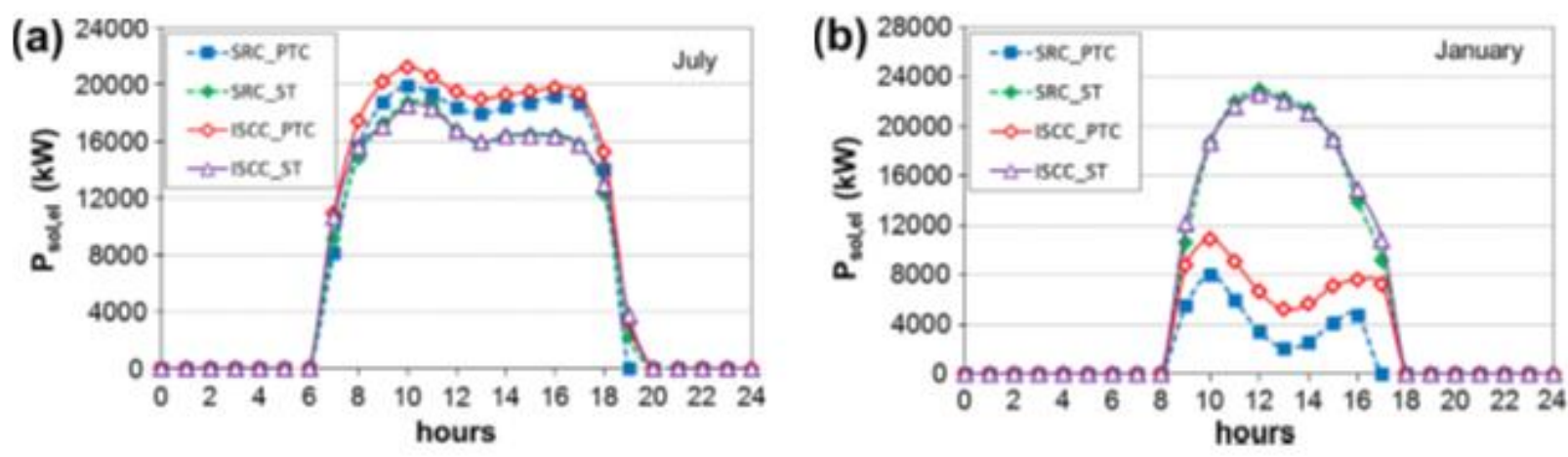

Figure 8: Hourly solar power production on a day in July (a) and January (b) [118] Figure 8 shows the performance of ST and PT in four different systems in a given day in July and January to understand the performance characteristics in summer and winter time.

System which have been considered in the model are Solar Rankine Cycle Parabolic Trough Collector (SRC--PTC), Solar Rankine Cycle Solar Tower (SRC_ST), Integrated Solar Combined Cycle Parabolic Trough Collector (ISCC_PTC), Integrated Solar Combined Cycle Solar Tower (ISCC_ST).

The simulation results in Figure 8 show that, in summer time both systems of PT performs better than ST systems. However, parabolic trough energy generation reduces dramatically in winter due to cosine effects and incident angle modifier effects and heat losses. ST performs steadily through-out the year which proves its superiority of yearly solar to energy conversion efficiency.
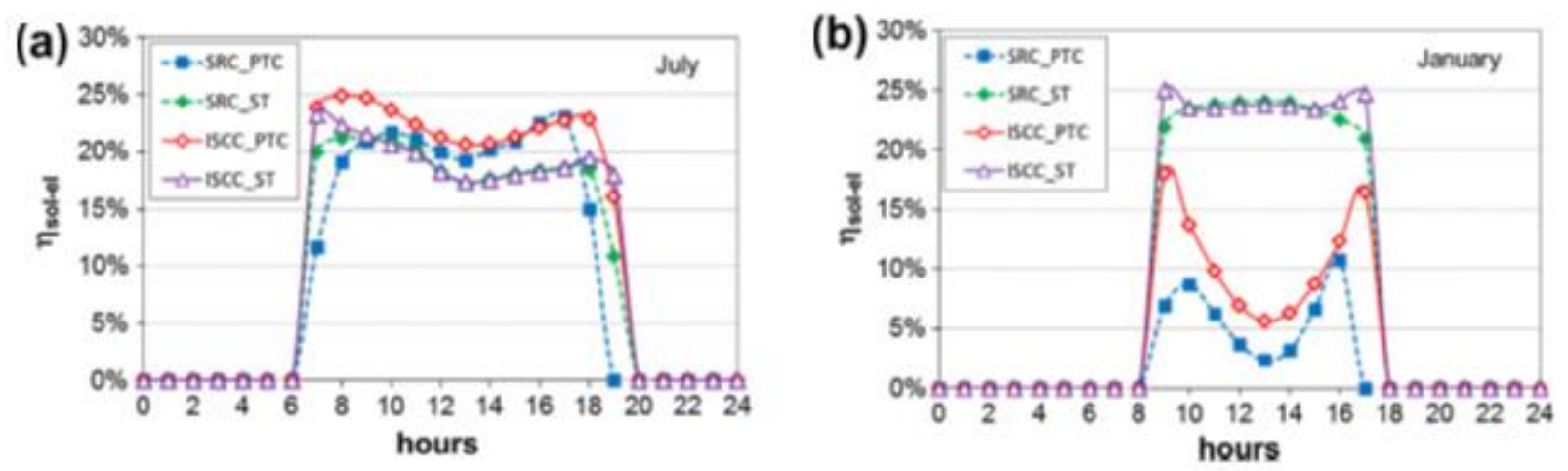

Figure 9. Hourly solar-to-electric efficiency on a day in July (a) and January (b) [118]. 
In figure 9, the efficiency curve of both ST and PT are presented. Values of nsol-el as high as $25 \%$ are obtained by solar tower plants in winter time (Fig. 9b), when low ambient temperatures make the condensing pressure fall, thus increasing the steam/bottoming cycle efficiency. The solar-to-electric efficiency of the PTC plants is strongly affected by the cosine effect. Solar-to-electric efficiency are lower than $10 \%$ in the central hours of a January day, increases up to $23 \%$ (SRC) or $25 \%$ (ISCC) in July.

Pitz Paal et.al [128] compared different CSP technologies from where he presented a correlation between temperature vs efficiency of each system. The correlation provides an understanding the maximum efficiency on different state of temperatures of each technology. The efficiency is measured as:

$$
\eta_{\max }=\eta_{\text {th, Carnot }} \times \eta_{\text {Absorber }}
$$

Assuming the obtained absorber temperature is equal to process temperature.

$$
T_{\text {Absorber }}=T_{\text {Process }}
$$

Figure 10 shows that at higher temperature a Stirling dish gives higher efficiency followed by solar tower. Solar tower performs best between around $1000 \mathrm{~K}\left(727^{\circ} \mathrm{C}\right)$ to $1300 \mathrm{~K}\left(1027^{\circ} \mathrm{C}\right)$ which gives a fare range of options for heat and power generation.

In comparison to that the parabolic trough gives a smaller window for CHP generation with optimum efficiency. Maximum efficiency spectrum is in between $700 \mathrm{~K}\left(427^{\circ} \mathrm{C}\right)$ to $750 \mathrm{~K}$ $\left(477^{\circ} \mathrm{C}\right)$. The obtainable maximum efficiency is better in solar tower where it offers around $65 \%$ in comparison to $50 \%$ efficiency of parabolic trough. The flat plate solar concentrators are the least in producing heat and thus less efficient in CHP generation.

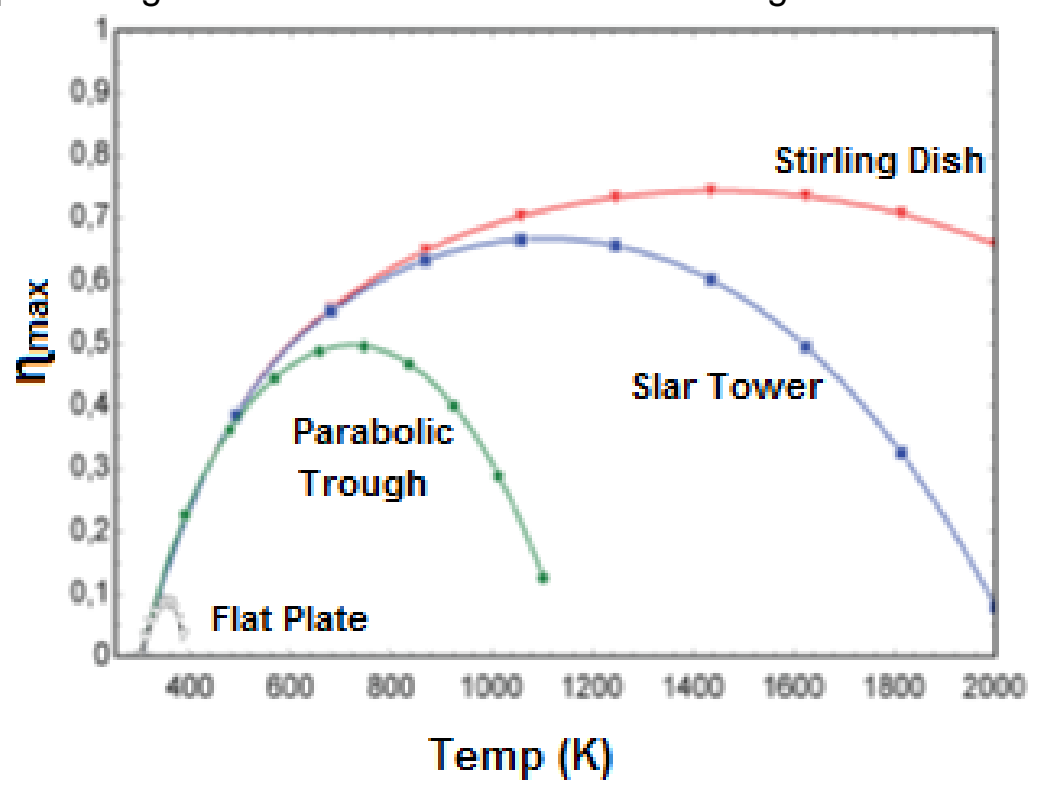

Figure 10: Temperature vs Efficiency curve of CSP system [128] 
The capital costs for the solar field and receiver system are a larger percentage of the total costs in solar tower systems, while the thermal energy storage and power block costs are a smaller percentage [129]. As shown in table 3, the area used to generate per MWh for ST is relatively higher than parabolic trough and significantly higher than LF and PT, it is apparently clear that ST draws higher capital cost in comparison to other two. However, according to International Renewable Energy Agency report in 2012 there is no CSP power plants using PT and LF are using thermal storage system, which means those plant only can generate electricity during day time. Therefore, solar tower can potentially lower the lavalized cost of energy (LCOE) by increasing the capacity factor using thermal energy storage system.

\subsection{Biomass Standalone}

A comparison of gasification, combustion, pyrolysis and pressurised gasification and gas turbine combined cycle, IGCC for power generation was found that the feed expenditure in the combustion systems is the highest of the systems at any capacity which leads to a low system efficiencies shown in Figure 11 [127].

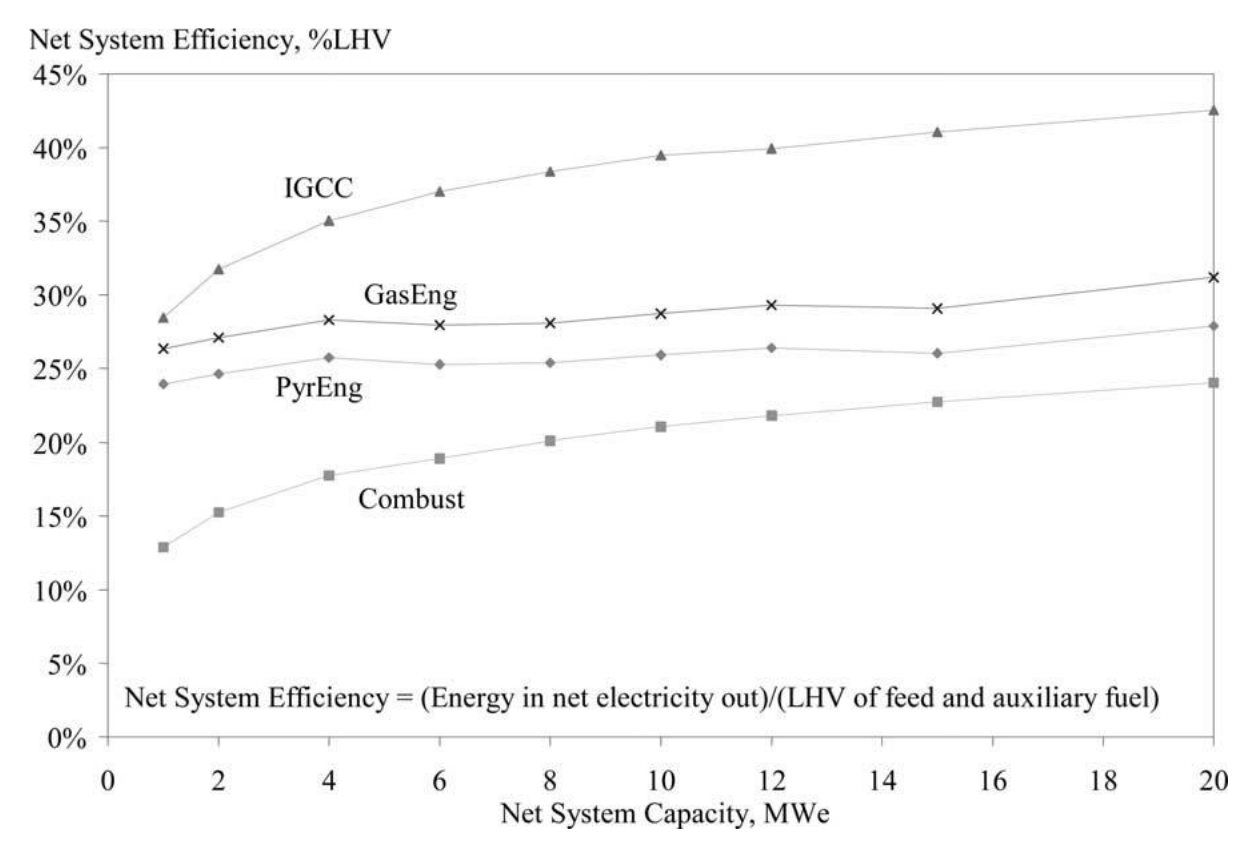

Figure 11: Comparison of efficiencies for biomass to electricity systems. [127]

This high feedstock expenditure is countered by low capital expenditure as a result of the low total plant costs shown in Figure 12. Low capital payback costs along with low overheads and maintenance costs and relatively lower labour costs are also the advantages of combustion system. Both low capital costs and low labour requirements are the key drivers of various well established power plants using biomass combustion technology. 


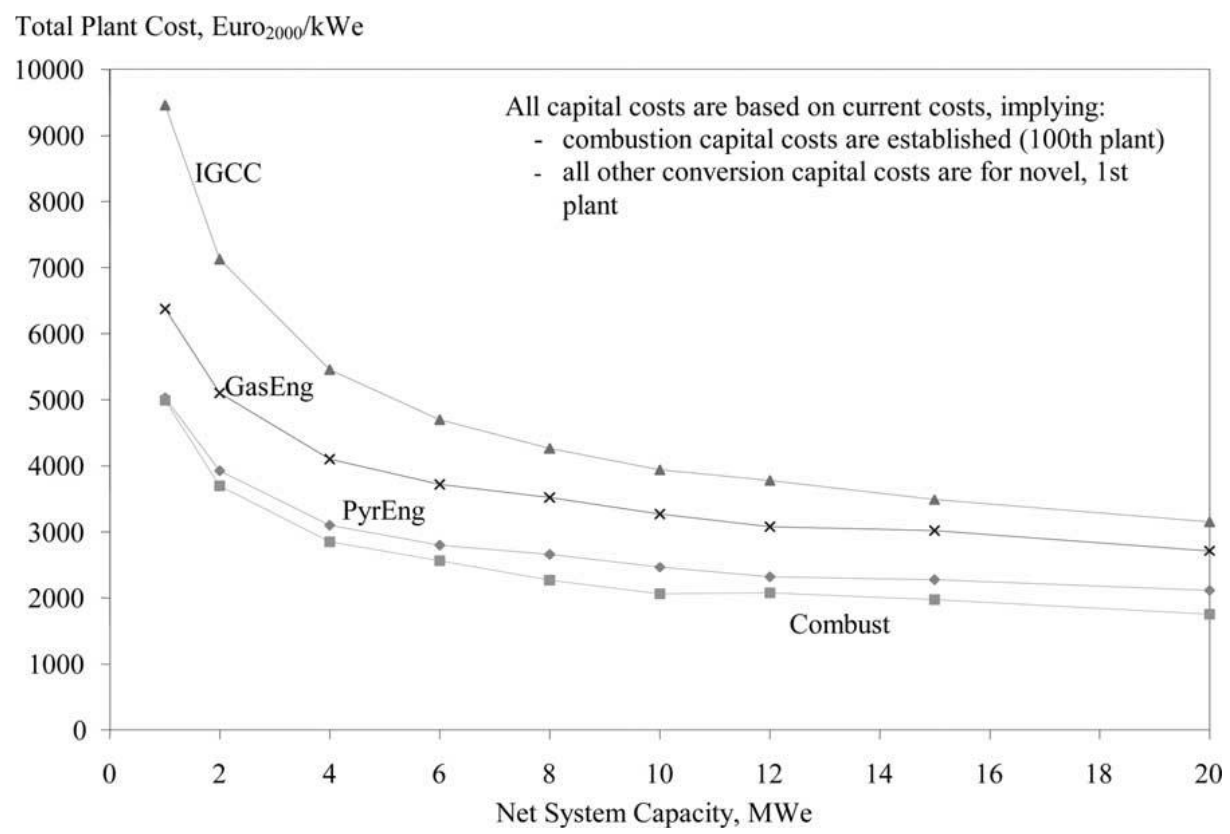

Figure 12: Comparison of total plant costs for biomass to electricity systems. [127]

It appears from the study that despite lower system efficiency of biomass combustion, this technology is widely adopted for power generation due to its economic competitiveness over other biomass systems. Figure 13, also gives a positive impression for biomass combustion in terms of biomass to electricity production costs, calculated between four systems at capacities from 1 to $20 \mathrm{MWe}$. The figure shows combustion gives cheaper electricity production in comparison to other biomass systems [127].

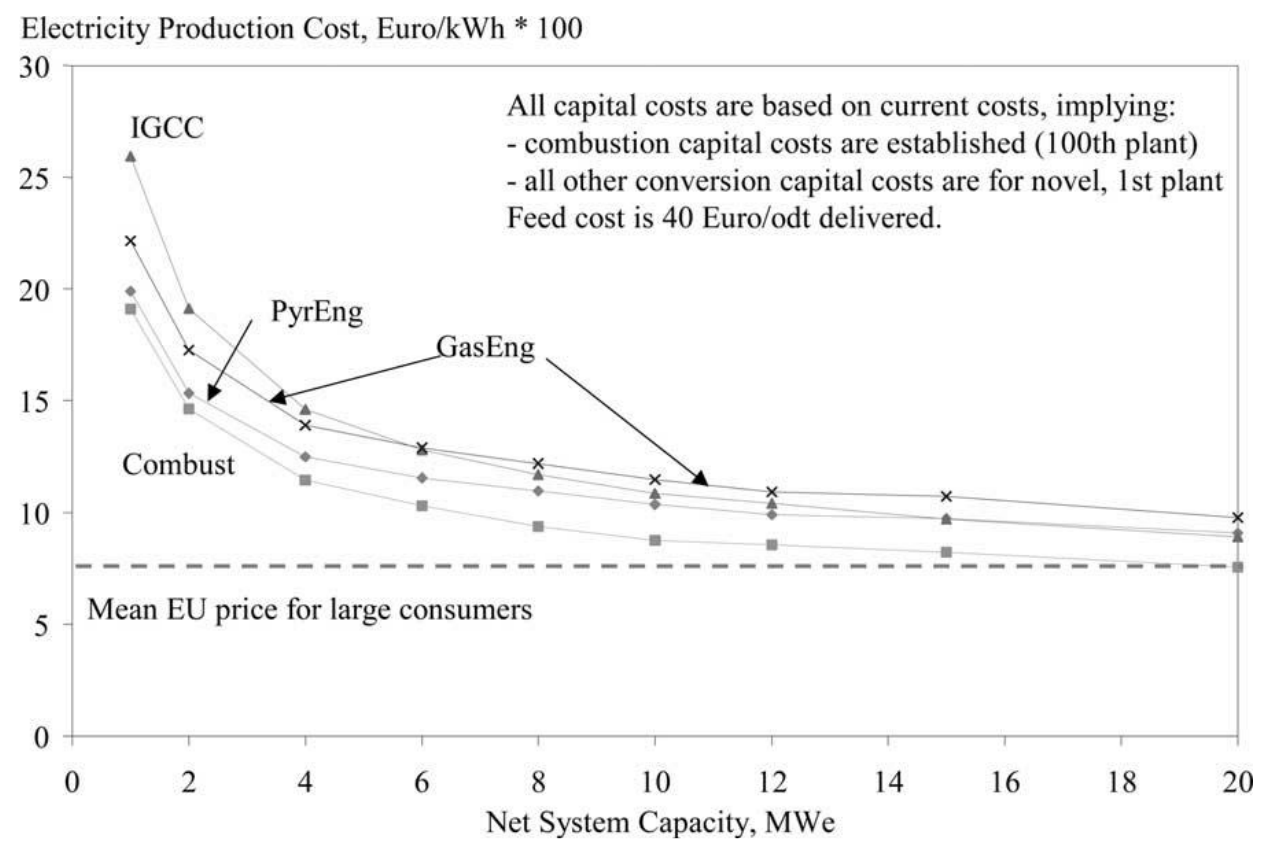

Figure 13: Comparison of electricity production costs for biomass to electricity systems. [127] 


\section{Simulation Result}

TRNSYS 17 is used for simulation where Thermal Energy System Specialists (TESS) is selected for the component library. Barajas Airport,Madrid, (TRNSYS weather model ESMadrid-Barajas-82210) is selected for location of all following models (Fig: 14,16,18). These models consider Parabolic trough (PT) and Steam Boiler as biomass system. Solar field consists of 26 rows, although only 14 rows are shown in the following pictures. Inlet working fluid temperature of single $\mathrm{PT}$ loop is $90^{\circ} \mathrm{C}$ and outlet temperature is around $385^{\circ} \mathrm{C}$. The hybrid power block is desiged to produce $3.2 \mathrm{MW}$ electivity per hour.

Following schemetic gives solar thermal energy yeild for 7 days of the location (Barajas Airport,Madrid). The result in figure 15 shows that inlet temperature of the working fluid is $90^{\circ} \mathrm{C}$ which then travels through a loop of parabolic trough giving outlet temperature around 385$395^{\circ} \mathrm{C}$.

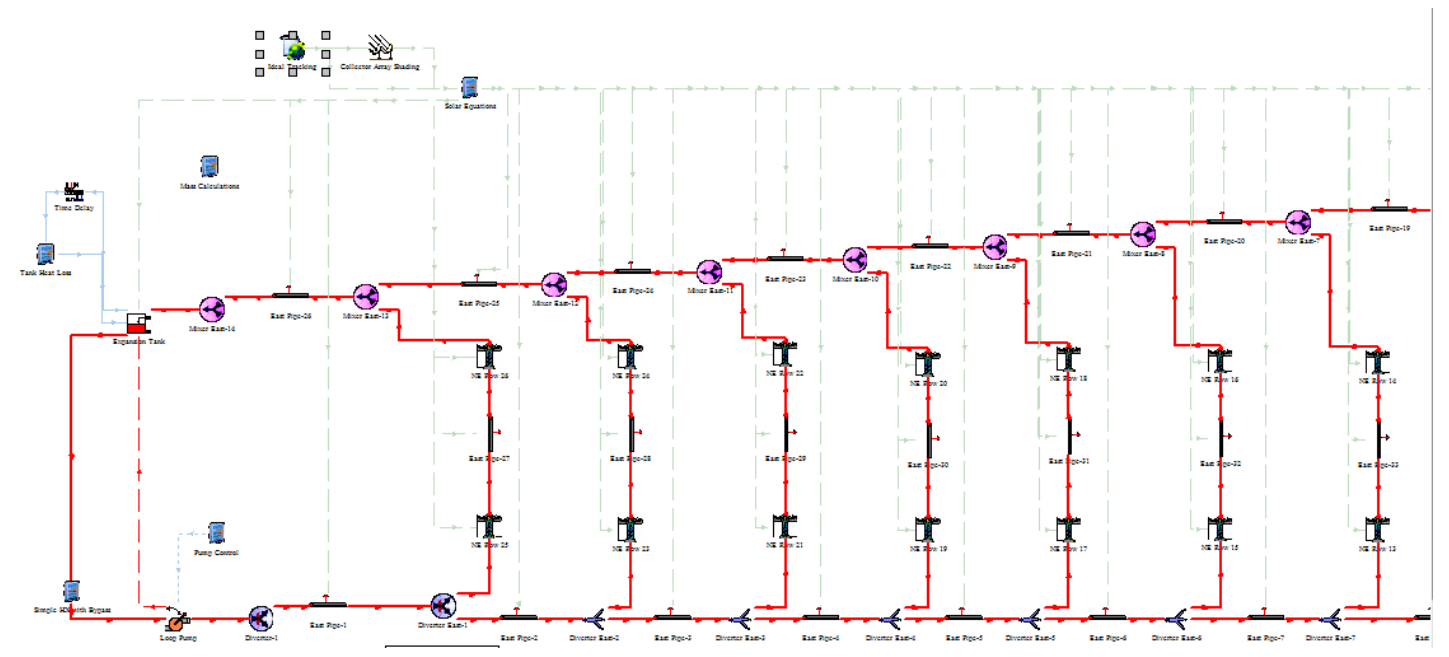

Fig: 14: Schematic of Solar Field.

Temperature (C) - ReturnTemp Control Signal

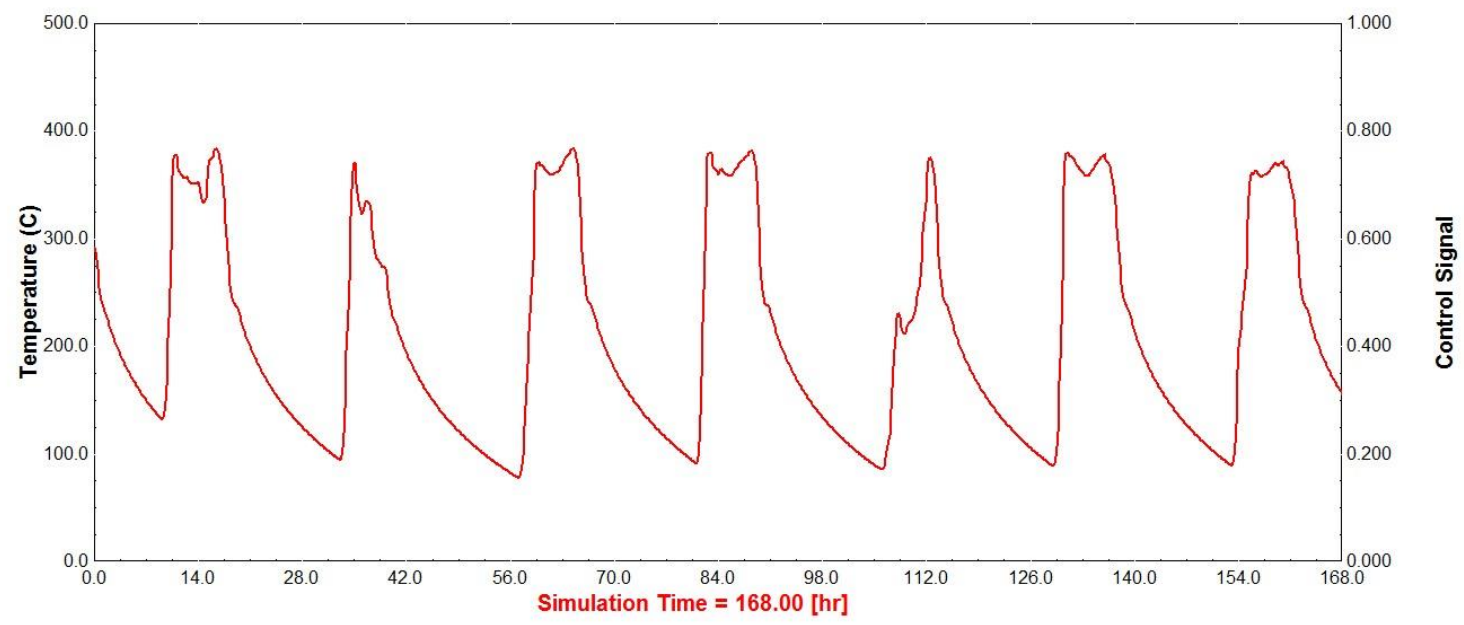

Fig: 15: Hourly Solar Irradiation of Barajas Airport,Madrid. 
Figure 16 is a representation of standalone solar and biomass systems. There are two sets of power block, one is connected with the solar field and the other is connected with steam boiler. Thus fiving power output through two different power grid. Result of the simulation model in the Figure 17 shows required energy for biomass boiler (red line), power production from solar (blue line) and power production from biomass (pink line). Due to system parameter constrain of TRNSYS17, required energy of biomass fired steam boiler is labelled as MJ/hr. All other results in Figure 17 and 19 are presented with MW/hr. Biomass boiler requires energy of $3 \mathrm{MJ} / \mathrm{hr}$. Power production from solar correlates Figure 15 as the steam outlet temperature gives the maximum thermal output from solar field. Thus giving electricity only for daytime. However, the biomass system produce constant electricity with the constant use of biomass resources. To reduce the biomass resource usages and a hybrid solar-biomass system is designed.

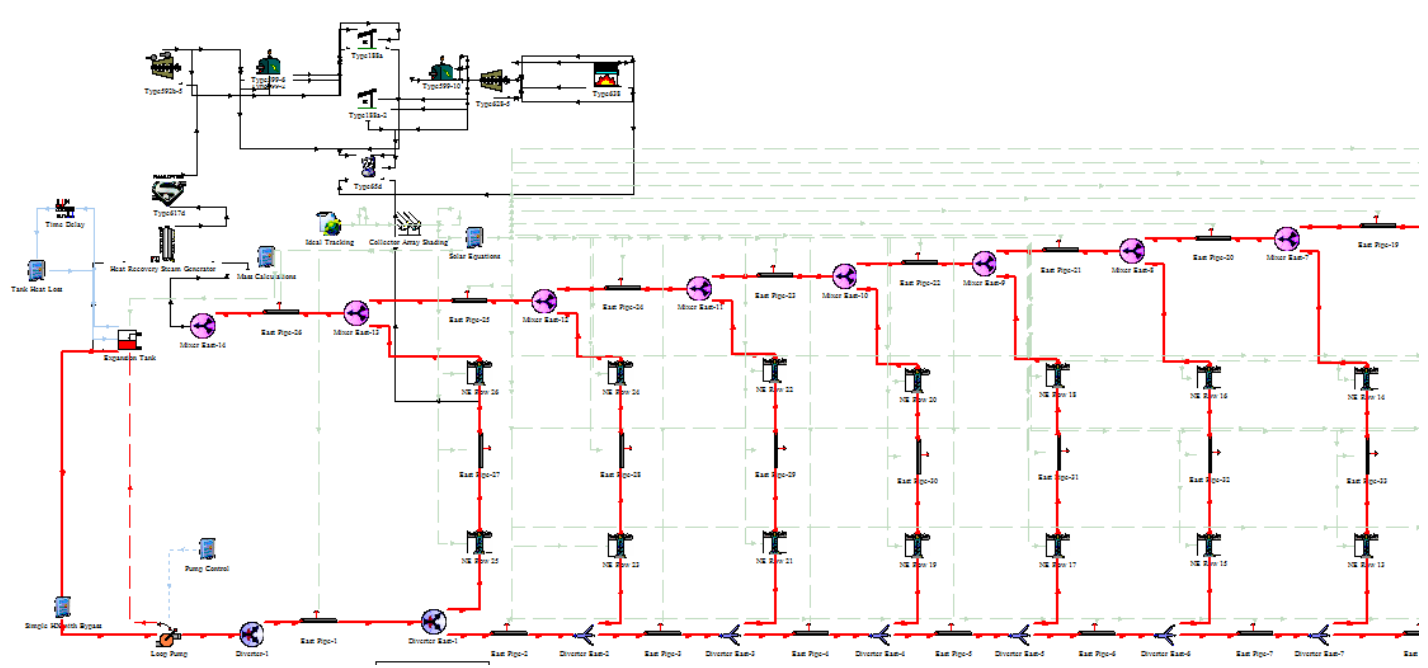

Fig: 16: Standalone solar and biomass power plant schematic

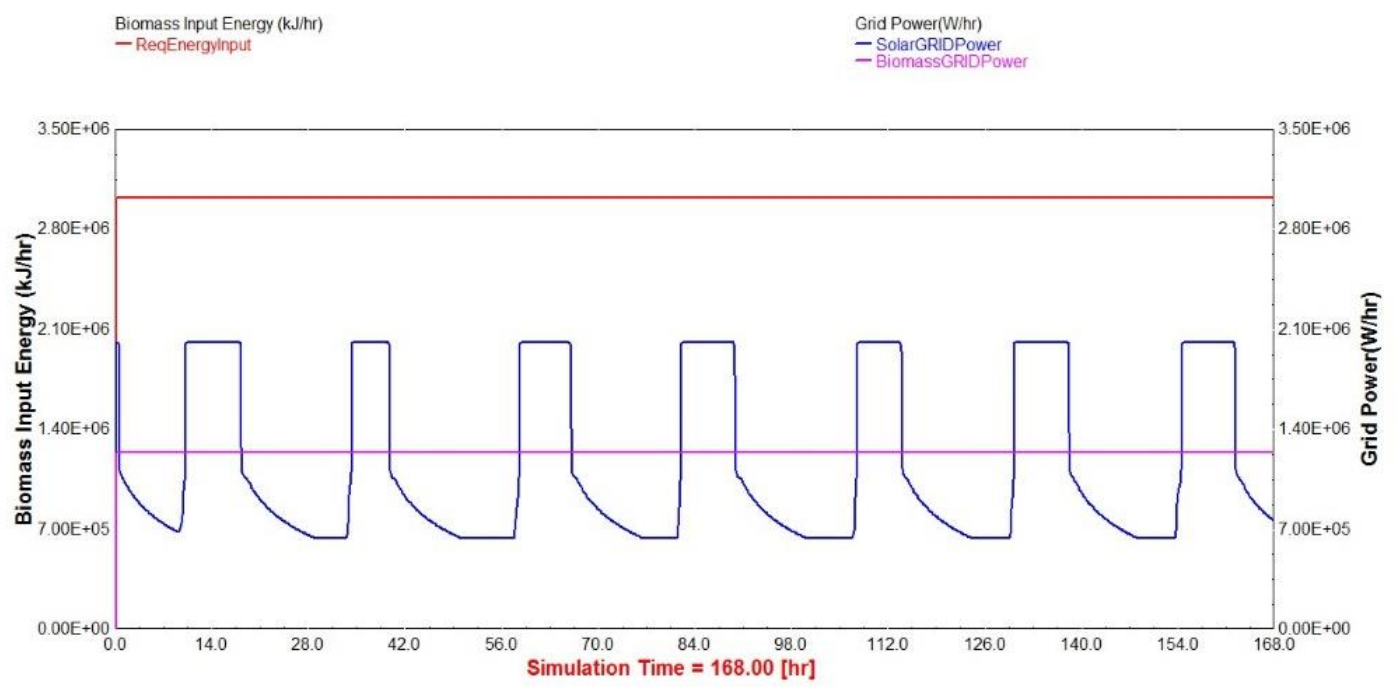

Fig: 17: Hourly power production from standalone solar and biomass systems 
Figure 18 merges two different systems of previous model into one system. Biomass fired steam boiler is connected just after the steam boiler to maintain the steam temperature according to the requirement of steam turbine. All other configuration of the system were kept same. The result in Figure 19 shows that the electricity generation is well up to the desired level, however, the biomass energy input is reduced inversely with the relation to Figure 15. As the system gains thermal energy during day time, the biomass usages goes zero. Biomass system only comes into effect when there is no sun irradiation.

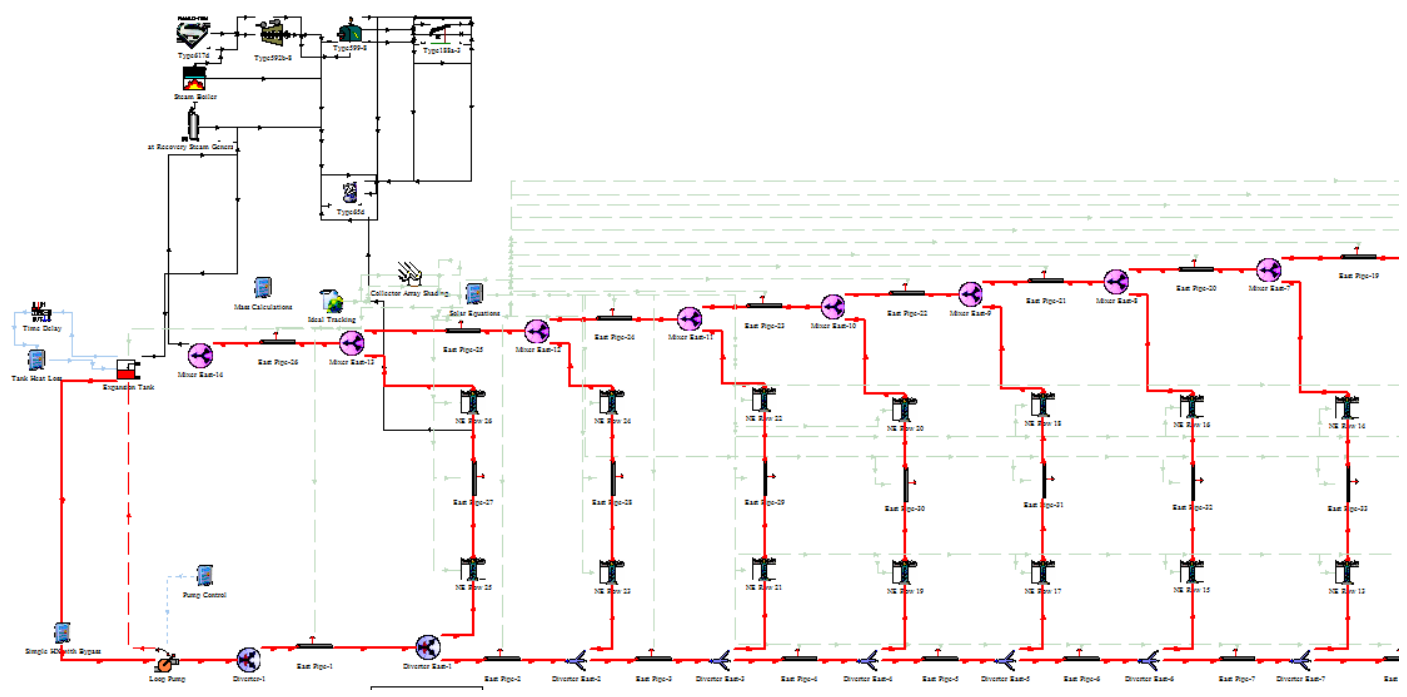

Fig: 18: Hybrid solar-biomass power plant schematic

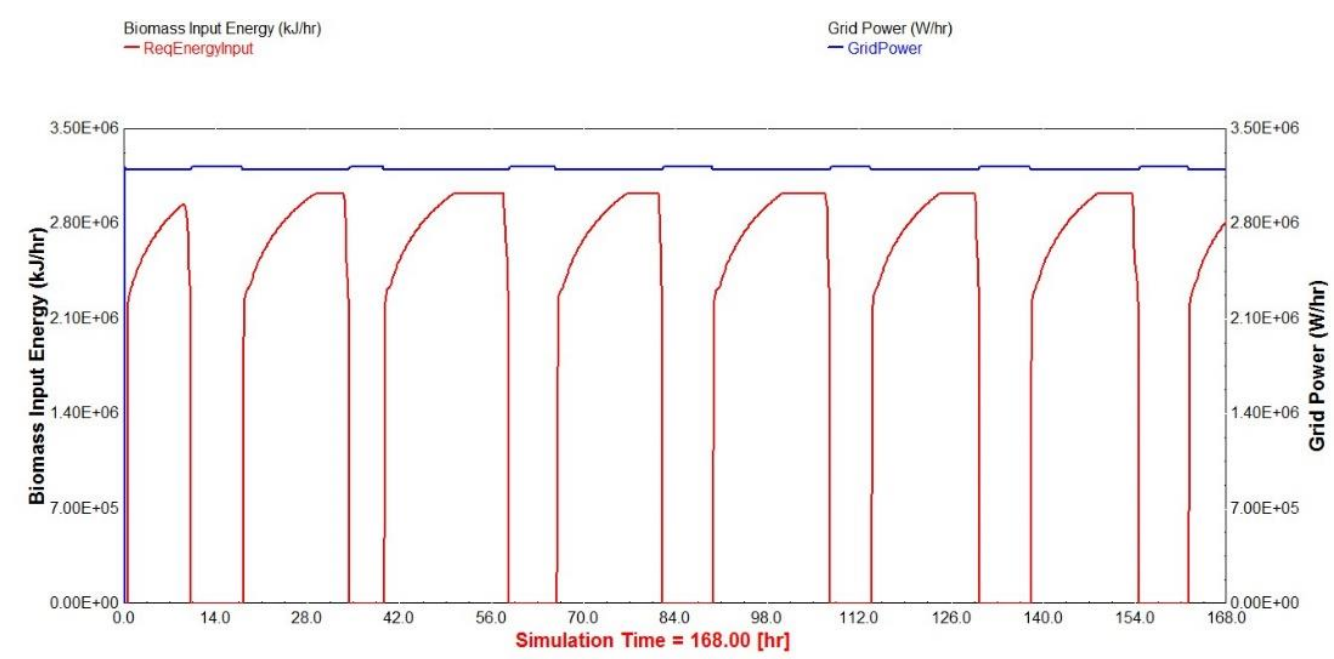

Fig: 19: Hourly power production from Hybrid solar-biomass system.

\section{Discussion and Conclusion}

It appears that Solar Tower (ST) is the best possible CSP technology for CHP generation hybrid system. Figure 10 shows that the effective working temperature range is very limited for flat plate solar concentrators [19]. PT efficiency decreases dramatically after $750 \mathrm{~K}\left(477^{\circ} \mathrm{C}\right)$. ST gives relatively better working temperature range over PT and LF. However, as ST is not 
as proven technology as Parabolic Trough (PT) due to its relatively higher land use and complex technical operations. Parabolic Trough may be suitable for hybridization as it has good summer performance as presented on figure $8 \& 9$ but is more suitable to be backed-up by biomass in winter. Higher optical and heat losses of linear Fresnel (LF) may not make it due the best option for hybridization. The PV system however may be useful for small scale power generation while integrated with national grid.

Biomass technology selection is heavily depended on availability of biomass resources, capital and operating cost. Deployment of biomass plant should consider a good availability of biomass resources or the plant may end up with a high operating cost. Regardless the efficiency of biomass systems different research shows that among all biomass technology, combustion system is proved to be most economically proven technology for biomass to electricity conversion.

Hybrid CSP and biomass power plants are interesting option for future dispatchable renewable electricity generation. The challenges are (i) moderate capacity factors (ii) high TES costs (iii) the necessity to build a large biomass collection structure (iv) the volatility of the biomass price and ( $v$ ) low feed-in tariffs. The hybridization of these technologies increases power plant capacity factors (when compared to a solar only) and reduces biomass consumption (when compared to a biomass only power plant.

\section{References:}

[1] Peterseim JH, White S, Tadros A, Hellwig U. Concentrating solar power hybrid plants - Enabling cost effective synergies. Renew Energy 2014;67:178-85.

[2] Erin Voegele, A biomass-solar hybrid plant begins operations in Spain, available at: http://www.biomassmagazine.com/articles/8546/a-biomass-solar-hybrid-plant-beginsoperations-in-spain, accessed on October 15, 2013.

[3] Abantia. Borges installed solar thermal power generation turbine, a turning point for its implementation. Available at: www.abantia.com/noticiasprensa/en_noticias/28/theinstallation-of-the-solar-field-termosolar-borgesthe-first-plant-to-combine-thermaland-biomass-has-started;

[4] Peterseim. J. H, Hellwig. U, Tadros. A, White. S, Hybridisation optimization of concentrating solar thermal and biomass power generation facilities, Science direct Solar Energy 99, pp 203-214,

[5] Peterseim JH, White S, Tadros A, Hellwig U. Concentrated solar power hybrid plants, which technologies are best suited for hybridisation? Renew Energy 2013;57:520-32.

[6] Cot. A, Amettler. A , Vall-Llovera J, Aguilo J, Arque JM. Termosolar Borges: A Thermosolar Hybrid Plant with Biomass. Third Int Symp Energy from Biomass Waste 2010.

[7] Nixon J.D, Dey PK, Davies P a. The feasibility of hybrid solar-biomass power plants in India. Energy 2012;46:541-54

[8] Peterseim JH, White S, Tadros A, Hellwig U. Integrated solar combined cycle plants using solar power towers to optimise plant performance. Solar PACES 2012. 
[9] Zhang HL, Baeyens J, Degreve J, Caceres G. Concentrated solar power plants: review and design methodology. Renewable and Sustainable Energy Rev 2013;22:466-81.

[10] Coelho B, Oliveira A, Schwarzbözl P, Mendes A. Biomass and central receiver system (CRS) hybridization: Integration of syngas/biogas on the atmospheric air volumetric CRS heat recovery steam generator duct burner. Renew Energy 2015;75:665-74.

[11] Servert. J, San Miguel. G, Lopez. D, Hybrid Solar- Biomass Plants For Power Generation; Technical And Economic Assessment, Global NEST Journal, Vol 13, No 3, pp 266-276, 2011.

[12] Srinivas. T, Reddy.B.V, Hybrid solar-biomass power plant without energy storage, Reference: CSITE22, Appeared in: Case Studies in Thermal Engineering, 232014. Available at: http://www.sciencedirect.com/science/article/pii/S2214157X14000057.

[13] Kaushika N, Mishra A, Chakravarty M. Thermal analysis of solar biomass hybrid cogeneration plants. International Journal of Sustainable Energy 2005; 24(4):175e86.

[14] Behar O, Khellafb A, Mohammedia K. A review of studies on central receiver solar thermal power plants. Renewable and Sustainable Energy Review 2013;23:12e39.

[15] Hussain.C.M.I, Muppala.S, Chowdhury.N.H, Adnan.A, Cost Analysis of Concentrated Solar Power Plant with Thermal Energy Storage System in Bangladesh, International Journal of Enhanced Research in Science Technology \& Engineering, ISSN: 23197463, Vol. 2 Issue 4, April-2013, pp: 79-87.

[16] Long $\mathrm{H}$, Li X, Wang H, Jia J. Biomass resources and their bioenergy potential estimation: A review. Renew Sustain Energy Rev 2013;26:344-52.

[17] Welfle A, Gilbert P, Thornley P. ScienceDirect Increasing biomass resource availability through supply chain analysis. Biomass and Bioenergy 2014;70: 249-66.

[18] Welfle A, Gilbert P, Thornley P. ScienceDirect Increasing biomass resource availability through supply chain analysis. Biomass and Bioenergy 2014;70:249-66.

[19] Iftekhar Hussain.C.M., Duffy A, Norton B. A Comparative Technological Review of Hybrid CSP-Biomass CHP Systems in Europe, International Conference on Sustainable Energy \& Environmental Protection, Paisley, UK 2015;122-30

[20] De WitM, Faaij A. European biomass resource potential and costs. Biomass and Bioenergy2010;34: 188-202.

[21] Fischer G, Prieler S, van Velthuizen H, Lensink SM, Londo M, de Wit M. Biofuel production potentials in Europe: sustainable use of cultivated land and pastures, Partl: Land productivity potentials. Biomass and Bioenergy 2010; 34: 159-72.

[22] De Wit M, Londo M, Faaij A. Productivity developments in European agriculture: relations to and opportunities for biomass production. Renewable and Sustainable Energy Reviews 2011; 15:2397-412.

[23] Faraco V, Hadar Y. The potential of lingocellulosic ethanol production in the Mediterranean Basin. Renewable and Sustainable Energy Reviews 2011;15:252-66.

[24] Steubing B, Zah R, Waeger P, Ludwig C. Bioenergy in Switzerland: Assessing the domestic sustainable biomass potential. Renewable and Sustainable Energy Reviews 2010;14:2256-65.

[25] Karaj SH, Rehl T, Leis H, Müller J. Analysis of biomass residues potential for electrical energy generation in Albania. Renewable and Sustainable Energy Reviews 2010;14:493-9.

[26] Szymańska D, Chodkowska-Miszczuk J. Endogenous resources utilization of rural areas in shaping sustainable development in Poland. Renewable and Sustainable Energy Reviews 2011;15:1497-501.

[27] Lotze-Campen H, Popp A, Beringer T, Müller C, Bondeau A, Rost S, et al. Scenarios of global bioenergy production: The trade-offs between agricultural expansion, intensification and trade. Ecological Modelling 2010;221:2188-96.

[28] Freitas S, Catita C, Redweik P, Brito MC. Modelling solar potential in the urban environment: State-of-the-art review. Renewable Sustainable Energy Revieve 2015;41:915-31.

[29] Badescu V, Dumitrescu A. Simple models to compute solar global irradiance from the CMSAF product Cloud Fractional Coverage. Renew Energy 2014;66:118-31. 
[30] Gueymard C a. Clear-sky irradiance predictions for solar resource mapping and largescale applications: Improved validation methodology and detailed performance analysis of 18 broadband radiative models. Soarl Energy 2012;86:2145-69..

[31] Widén J, Carpman N, Castellucci V, Lingfors D, Olauson J, Remouit F, Variability assessment and forecasting of renewables: A review for solar, wind, wave and tidal resources. Renew Sustain Energy Rev 2015;44:356-75.

[32] Rom R. Reconstruction of long-term direct solar irradiance data series using a model based on the Cloud Modi fi cation Factor 2015;77:115-24.

[33] Ruiz-Arias J a., Quesada-Ruiz S, Fernández EF, Gueymard C a. Optimal combination of gridded and ground-observed solar radiation data for regional solar resource assessment. Solar Energy 2015;112:411-24.

[34] "SolarGIS-Solar-map-Europe-en" by SolarGIS (c) 2011 GeoModel Solar s.r.o.. Licensed under CC BY-SA 3.0 via Commons -

https://commons.wikimedia.org/wiki/File:SolarGIS-Solar-map-Europeen.png\#/media/File:SolarGIS-Solar-map-Europe-en.png

[35] Law EW, Prasad A a., Kay M, Taylor R a. Direct normal irradiance forecasting and its application to concentrated solar thermal output forecasting - A review. Solar Energy 2014;108:287-307.

[36] Bojanowski JS, Vrieling A, Skidmore AK. Calibration of solar radiation models for Europe using Meteosat Second Generation and weather station data. Agric For Meteorol 2013;176:1-9.

[37] Huld T, Müller R, Gambardella A. A new solar radiation database for estimating PV performance in Europe and Africa. Sol Energy 2012;86:1803-15.

[38] Bojanowski JS, Vrieling A, Skidmore AK. A comparison of data sources for creating a long-term time series of daily gridded solar radiation for Europe. Solar Energy 2014;99:pp152-71.

[39] Journée M, Müller R, Bertrand C. Solar resource assessment in the Benelux by merging Meteosat-derived climate data and ground measurements. Sol Energy 2012;86:3561-74.

[40] Gueymard C a. A review of validation methodologies and statistical performance indicators for modeled solar radiation data: Towards a better bankability of solar projects. Renew Sustain Energy Rev 2014;39:1024-34.

[41] Scharmer K, Greif J. Vol . 1: Fundamentals and maps. vol. 1.

[42] European Solar irradiation Map, Annual Data $\mathrm{kWh} / \mathrm{m}^{2}$. Available at: http://pvshop.eu/Solar-Irradiation-in-Europe-kWh-per-m2

[43] Romero S.M , CSP: Solar Resource Assessment, Available at: https:// www. esmap.org/sites/esmap.org/files/ESMAP_IFC_RE_CSP_Training_World_Bank_Rom ero.pdf

[44] Burnett D, Barbour E, Harrison GP. The UK solar energy resource and the impact of climate change. Renewable Energy 2014; 71: 333-43.

[45] Moreno a., Gilabert M a., Martínez B. Mapping daily global solar irradiation over Spain: A comparative study of selected approaches. Solar Energy 2011;85: 2072-84.

[46] Li Z, Boyle F, Reynolds A. Domestic application of solar PV systems in Ireland: The reality of their economic viability. Energy 2011;36:5865-76.

[47] Li Z, Reynolds A, Boyle F. Domestic integration of micro-renewable electricity generation in Ireland - The current status and economic reality. Renew Energy 2014;64:244-54. [48] Rourke FO, Boyle F, Reynolds A. Renewable energy resources and technologies applicable to Ireland. Renewable and Sustainable Energy Review 2009;13:1975-84.

[49] Black K, Davis P, Lynch P, Jones M, McGettigan M, Osborne B. Long-term trends in solar irradiance in Ireland and their potential effects on gross primary productivity. Agric For Meteorol 2006;141:118-32.

[50] T.E. Agency. Solar Energy Resource Report; 2007.

[51] Hoefnagels. R, Junginger,M, Resch.G, Matzenberger.J, Panzer.C, 
Development of a tool to model European biomass trade Report for IEA Bioenergy $T$ Task 40. 2013,

[52] Baharoon DA, Rahman HA, Omar WZW, Fadhl SO. Historical development of concentrating solar power technologies to generate clean electricity efficiently - A review. Renewable and Sustainable Energy Review 2015;41:996-1027.

[53] Zhu G, Wendelin T, Wagner MJ, Kutscher C. History, current state, and future of linear Fresnel concentrating solar collectors. Solar Energy 2014;103:639-52. doi:10.1016/j.solener.2013.05.021.

[54] European Academices Science Advisory Council (EASAC). Concentrating solar power: its potential contribution to a sustainable energy future. Available at: 〈http://www.easac.eu/file admin/Reports/Easac_CSP_Web-Final.pdf); 2011

[55] International Energy Agency (IEA). SolarPACES, energy technology network. Available at: 〈http://www.Solarpaces.org [retrieved 15.03.13].

[56] Greenpeace International, SolarPACES and ESTELA. Concentrating solar power outlook 2009 - why renewable energy is hot. Available at: 〈http://www.greenpeace.org/international/Global/international/planet-2/ report/2009/5/concentrating-solar-power-2009. pdf); 2009.

[57] Archimede Solar Energy (Angelantoni industrie). Available at: 〈http:// www.archimedesolarenergy.it [retrieved 05.01.13].

[58] Greenpeace International, SolarPACES and ESTELA. Concentrating solar power outlook 2009 - why renewable energy is hot. Available at:

〈http://www.greenpeace.org/international/Global/international/planet-2/ report/2009/5/concentrating-solar-power-2009. pdf); 2009.

[59] Valenzuela L. STE Plants with parabolic trough collectors. Available at: 〈http:// sfera.sollab.eu/downloads/Schools/Loreto_Valenzuela_Presentation.pdf);2012.

[60] Morin, G., Mertins, M., Kirchberger, J., Selig, M., 2011. Super NOVA - construction, control \& performance of steam superheating linear Fresnel collector. In: Presented at the 17th Solar PACES International Symposium, Granada, Spain.

[61] Morin, G., Dersch, J., Platzer, W., Eck, M., Haberle, A., 2012. Comparison of linear Fresnel and parabolic trough collector power plants. Solar Energy 86.

[62] Munoz, J., Martinez-Val, J.M., Ramos, A., 2011. Thermal regimes in solar-thermal linear collectors. Solar Energy 85, 857-870.

[63] Pino, F.J., Caro, R., Rosa, F., Guerra, J., 2012. Experimental validation of an optical and thermal model of a linear Fresnel collector system. Applied Thermal Engineering, $1-9$

[64] Solar paces technology characterization: solar dish engine. Available at: 〈http://www.solarpaces.org/CSP_Technology/docs/solar_dish.pdf〉.

[65] Norton B, Eames PC, Mallick TK, Huang MJ, McCormack SJ, Mondol JD, Enhancing the performance of building integrated photovoltaics. Sol Energy 2011;85:1629-64.

[66] Mondol JD, Yohanis YG, Norton B. Comparison of measured and predicted long term performance of grid a connected photovoltaic system. Energy Conversion Management 2007;48:1065-80.

[67] Mondol JD, Yohanis YG, Norton B. Solar radiation modelling for the simulation of photovoltaic systems. Renewable Energy 2008;33:1109-20.

[68] Mondol JD, Yohanis YG, Norton B. Optimising the economic viability of gridconnected photovoltaic systems. Applied Energy 2009;86:985-99.

[69] Ayompe, L. and Duffy, A. Feed-in tariff design for domestic scale grid-connected PV systems using high resolution household electricity demand data. Energy Policy (2013): 61; 619-627. http://dx.doi.org/10.1016/j.enpol.2013.06.102.

[70] Ayompe, L., Duffy, A., McCormack, S., \& Conlon, M. (2010) Validated real-time energy models for small-scale grid-connected PVsystems. Energy, vol.36, no.10, pp.4086-4091. 
[71] Bozkurt I, Karakilcik M. The daily performance of a solar pond integrated with solar collectors. Solar Energy 2012;vol.86;pp:1611-20.

[72] El-Sebaii a. a., Ramadan MRI, Aboul-Enein S, Khallaf a. M. History of the solar ponds: Renewable and Sustainable Energy Review 2011;15;pp3319-3325.

[73] Singh B, Gomes J, Tan L, Date A, Akbarzadeh a. Small Scale Power Generation using Low Grade Heat from Solar Pond. Procedia Eng 2012;49;pp:50-56.

[74] Tundee S, Srihajong N, Charmongkolpradit S. Electric Power Generation from Solar Pond Using Combination of Thermosyphon and Thermoelectric Modules. Energy Procedia 2014;48;pp:453-463.

[75] Pujol Nadal R, Martínez Moll V. Optical Analysis of the Fixed Mirror Solar Concentrator by Forward Ray-Tracing Procedure. J Sol Energy Eng 2012;134:031009.

[76] Li. L, Li H, Xu Q, Huang W. Performance analysis of Azimuth Tracking Fixed Mirror Solar Concentrator. Renew Energy 2015;75:722-32.

[77] Bradshaw.R.W. and Siegel.N.P, Molten Nitrate Salt Development For thermal Energy Storage In Parabolic trough Solar Power System", Proceedings of ES 2008 Energy Sustainability, Jacksonville, Florida USA

[78] Stoddard, M.C., et. al., SOLERGY, A Computer Code for Calculating the Annual Energy from Central Receiver Power Plants, Sandia National Laboratories, Livermore, CA: May. Report SAND86-8060.

[79] Wayne Doherty, Modelling of Biomass Gasification Integrated with a Solid Oxide Fuel Cell System, PhD Thesis Submitted in School of Mechanical and Design Engineering, Dublin Institute of Technology

[80] Basu P. Biomass gasification and pyrolysis: practical design and theory. Brulington, MA: Academic; 2010.

[81] Kirkels AF, Verbong GPJ. Biomass gasification: Still promising? A 30-year global overview. Renewable and Sustainable Energy Reviews 2011;15:471.

[82] Doherty,W.,Reynolds, A.Kennedy, D. (2015) Process Simulation of Biomass Gasification Integrated with a Solid Oxide Fuel Cell Stack. Journal of Power Sources 2015;277:292-303.

[83] Nussbaumer VT. verenum Overview on Technologies for Biomass Combustion and Emission Levels of Particulate Matter. 2010.

[84] IEA Bioenergy (Task 32), Biomass Combustion and Co-firing: An Overview

[85] Biomass for Electricity Generation by U.S. Department of Energy Federal Energy Management Program (FEMP) Last updated: 08-04-2011. Available at: http://www.wbdg.org/resources/biomasselectric.php

[86] Isabel Llorente Garcl , Jose' Luis A ' Ivarez, Daniel Blanco, Performance model for parabolic trough solar thermal power plants with thermal storage: Comparison to operating plant data, Solar Energy 85 (2011) pp. 2443-2460

[87] Javier Bonilla a, Luis Jose' Yebra, Sebastia'n Dormido, Eduardo Zarza, Parabolictrough solar thermal power plant simulation scheme,multi-objective genetic algorithm calibration and validation, Solar Energy 86 (2012),pp. 531-540

[88] Andrea Giostri, Marco Binotti, Marco Astolfi, Paolo Silva, Ennio Macchi, Giampaolo Manzolini,Comparison of different solar plants based on parabolic trough technology, Solar Energy 86 (2012) pp. 1208-1221

[89] Korbinian Kramer, Henning Helmers, The interaction of standards and innovation: Hybrid photovoltaic-thermal collectors, Solar Energy 98 (2013) 434-439

[90] Monia Chaabane, Wael Charfi, Hatem Mhiri, Philippe Bournot, Performance evaluation of concentrating solar photovoltaic and photovoltaic/thermal systems, Solar Energy 98 (2013) pp. 315-321

[91] G. Franchini, A. Perdichizzi, S. Ravelli, G. Barigozzi, A comparative study between parabolic trough and solar tower technologies in Solar Rankine Cycle and Integrated Solar Combined Cycle plants, Solar Energy 98 (2013) 302-314 
[92] N.S. Suresh, N.C. Thirumalai 1, Badri S. Rao 2, M.A. Ramaswamy, Methodology for sizing the solar field for parabolic trough technology with thermal storage and hybridization, Solar Energy 110 (2014) pp.247-259

[93] G.C. Bakos, D. Parsa, Technoeconomic assessment of an integrated solar combined cycle power plant in Greece using line-focus parabolic trough collectors, Renewable Energy 60 (2013) 598-603

[94] A. Heimsath, F. Cuevas, A. Hofer, P. Nitz, W.J. Platzer, Linear Fresnel collector receiver: heat loss and temperatures, Energy Procedia 49 (2014) 386 - 397.

[95] A. Mohamad, J. Orfi and H. Alansary, Heat losses from parabolic trough solar collectors, Int. J. Energy Res. 2014; 38:20-28

[96] Guangdong Zhu, Tim Wendelin, Michael J. Wagner, Chuck Kutscher,History, current state, and future of linear Fresnel concentrating solar collectors, Solar Energy 103 (2014) 639-652

[97] Rabi Ibrahim Rabady, Abeer Andrawes, Effective solar-thermal collector with concentration, Solar Energy 105 (2014) 438-444

[98] N.S. Suresh, N.C. Thirumalai, Badri S. Rao, M.A. Ramaswamy, Methodology for sizing the solar field for parabolic trough technology with thermal storage and hybridization, Solar Energy 110 (2014) 247-259

[99] M. Alguacila, C. Prietoa, A. Rodrigueza, J.Lohra, Direct steam generation in parabolic trough collectors, Energy Procedia 49 ( 2014 ) $21-29$

[100] R. N. HK. Feasibility Study of Photovoltaic (PV) Modules, and Biomass Generator to Supply Electricity to Auckland City, North Island Context-New Zealand. J Clean Energy Technol 2014;2:374-378.

[101] Pradhan SR, Bhuyan PP, Sahoo SK, Prasad GRKDS. Design of Standalone Hybrid Biomass \& PV System of an Off- Grid House in a Remote Area 2013;3:433-437.

[102] Rn HK. Feasibility Study: Photovoltaic Module and Biomass Based Hybrid Power System Connected to Grid- South Australia Context , Australia Harish Kumar RN 2013;2:14-22.

[103] Afzal A. Performance Analysis of Integrated Wind, Photovoltaic and Biomass Energy Systems 2011:818-25.

[104] Coates J, Solar T. SRP and Tessera Solar Announce 1 . 5 MW Maricopa Solar Plant with Stirling Energy Systems SunCatcher TM Technology in Peoria, Arizona 2009.

[105] Ortega JI, Burgaleta JI, Téllez FM. Central Receiver System Solar Power Plant Using Molten Salt as Heat Transfer Fluid. J Sol Energy Eng 2008;vol: 130/024501

[106] Peterseim JH, Tadros a., White S, Hellwig U, Landler J, Galang K. Solar tower biomass hybrid plants - Maximizing plant performance. Energy Procedia 2013;49:1197-206.

[107] Bhattacharjee S, Dey A. Techno-economic performance evaluation of grid integrated PV-biomass hybrid power generation for rice mill. Sustain Energy Technol Assessments 7, 2014, pp: 6-16.

[108] Itskhokine D, Lancereau Q, Benmarraze M, Bichotte M, Dubost L. ScienceDirect LFR500 project : getting to high temperature while maintaining the cost-competitive advantage of Linear Fresnel Reflectors 2015;00.

[109] J. H. Peterseim, A. Tadros, S. White, U. Hellwig, and F. Klostermann, "Concentrated solar power / Energy from Waste hybrid plants - creating synergies," in SolarPACES Conference, 2012.

[110] Peterseim JH, Tadros A, Hellwig U, White S. Increasing the efficiency of parabolic trough plants using thermal oil through external superheating with biomass. Energy Convers Manag 2014;77:784-93.

[111] Afzal A. Performance Analysis of Integrated Wind, Photovoltaic and Biomass Energy Systems 2011:818-25.

[112] Bhattacharjee S, Dey A. Techno-economic performance evaluation of grid integrated -biomass hybrid power generation for rice mill. Sustain Energy Technol Assessments 2014;7:6-16. doi:10.1016/j.seta.2014.02.005. 
[113] Coates J, Solar T. SRP and Tessera Solar Announce 1. 5 MW Maricopa Solar Plant with Stirling Energy Systems SunCatcher TM Technology in Peoria , Arizona 2009.

[114] Pradhan SR, Bhuyan PP, Sahoo SK, Prasad GRKDS. Design of Standalone Hybrid Biomass \& PV System of an Off- Grid House in a Remote Area 2013;3:433-7.

[115] R. N. HK. Feasibility Study of Photovoltaic (PV) Modules, and Biomass Generator to Electricity to Auckland City, North Island Context-New Zealand. J Clean Energy Technol 2014;2:374-8. doi:10.7763/JOCET.2014.V2.157.

[116] Rn HK. Feasibility Study: Photovoltaic Module and Biomass Based Hybrid Power Connected to Grid- South Australia Context , Australia Harish Kumar RN 2013;2:1422.

[117] Morin G, Dersch J, Platzer W, Eck M, Häberle A. Comparison of Linear Fresnel and Parabolic Trough Collector power plants. Sol Energy 2012;86,1-12.

[118] Franchini G, Perdichizzi a., Ravelli S, Barigozzi G. A comparative study between parabolic trough and solar tower technologies in Solar Rankine Cycle and Integrated Solar Combined Cycle plants. Sol Energy 2013;98:302-14.

[119] Nixon JD, Dey PK, Davies P a. Which is the best solar thermal collection technology for electricity generation in north-west India? Evaluation of options using the analytical hierarchy process. Energy 2010;35:5230-5240.

[120] Heimsath a., Cuevas F, Hofer a., Nitz P, Platzer WJ. Linear Fresnel Collector receiver: Heat loss and temperatures. Energy Procedia 2013;49:386-97.

[121] Pitz-Paal R. Parabolic Trough, Linear Fresnel, Power Tower A Technology Comparison Robert Pitz-Paal n.d.

[122] Sargent L. Assessment of Parabolic Trough and Power Tower Solar Technology Cost and Performance Forecasts Assessment of Parabolic Trough and Power Tower Solar Technology Cost and Performance Forecasts. Rep No NREL/SR-550-34440 2003:47.

[123] Dawoud B, Amer E, Gross D. Experimental investigation of an adsorptive thermal energy storage. Int J Energy Res 2007;31:135-47.

[124] Morin G, Dersch J, Eck M, Häberle A, Platzer W. Comparison of Linear Fresnel and Parabolic Trough Collector Systems - Influence of Linear Fresnel Collector Design Variations on Break Even Cost. SolarPACES? 2009.

[125] Pitz-Paal R, Concentrators L. Line Concentrators for Power Generation : Parabolic Trough and Linear Fresnel, accessed on: 12/04//2015; Available at: http://www.iasspotsdam.de/sites/default/files/files/12.5-iass_pitz-paal.pdf

[126] Norton, B., (2014) Harnessing Solar Heat Lecture Notes in Energy Vol. 18 (Dordrecht: Springer)

[127] Bridgwater A. V, Tof A. J, Brammer J.G. A techno-economic comparison of power production by biomass fast pyrolysis with gasification and combustion. vol. 6. 2002.

[128] Pitz-Paal R. Parabolic Trough, Linear Fresnel, PowerTower A Technology Comparison. Available at http://www.iass-potsdam.de/sites/default/files/files/12.5-iass_pitz-paal.pdf

[129] Renewable energy technology: cost analysis series, International Renewable Energy Agency, Volume 1: Power Sector, issue2/5, June2012 